EUROPEAN CENTRAL BANK

WORKING PAPER SERIES

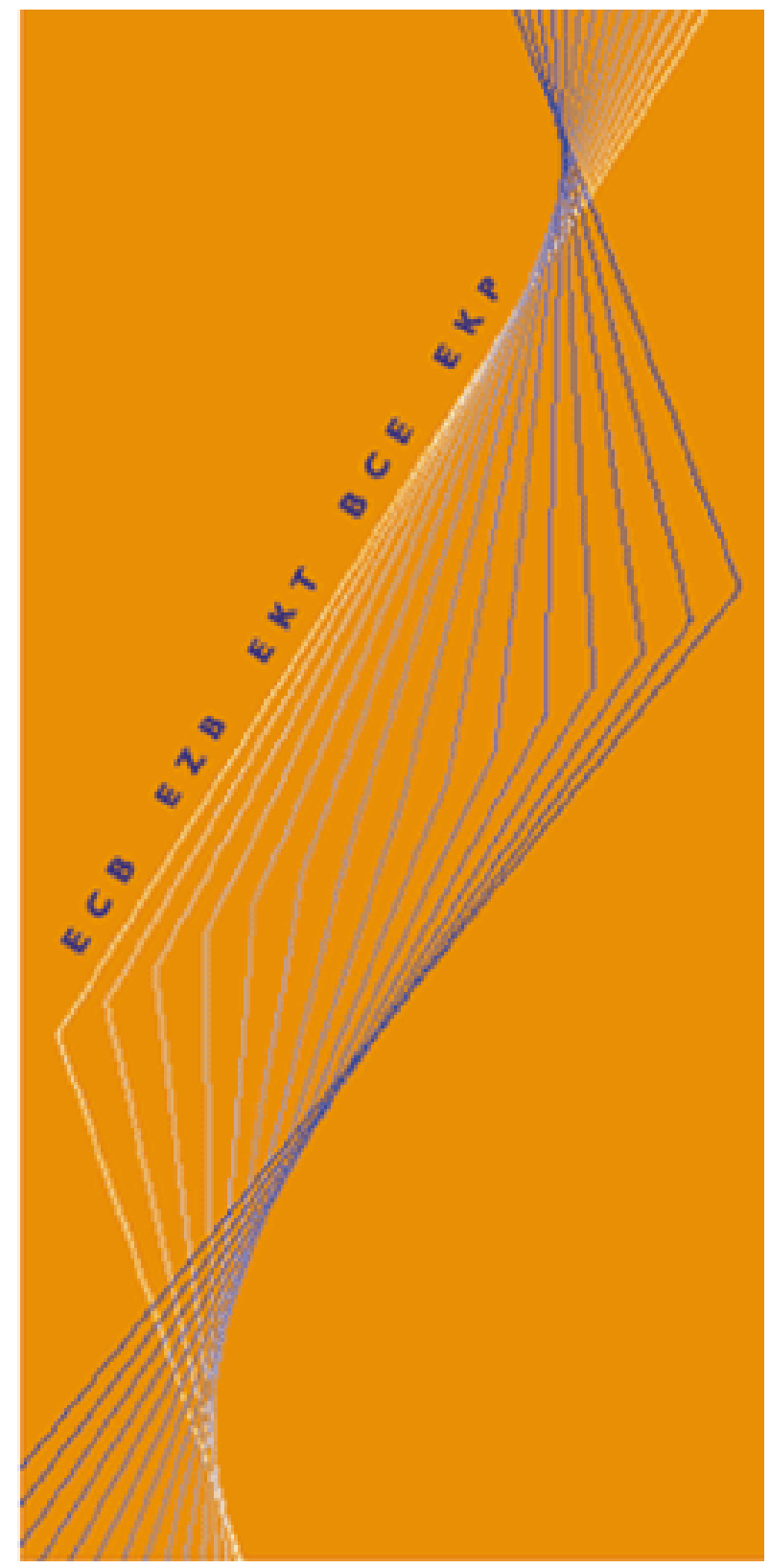

WORKING PAPER NO. 232

DESCRIBING THE FED'S CONDUCT WITH TAYLOR RULES: IS INTEREST RATE SMOOTHING IMPORTANT?

BY EFREM CASTELNUOVO

May 2003 


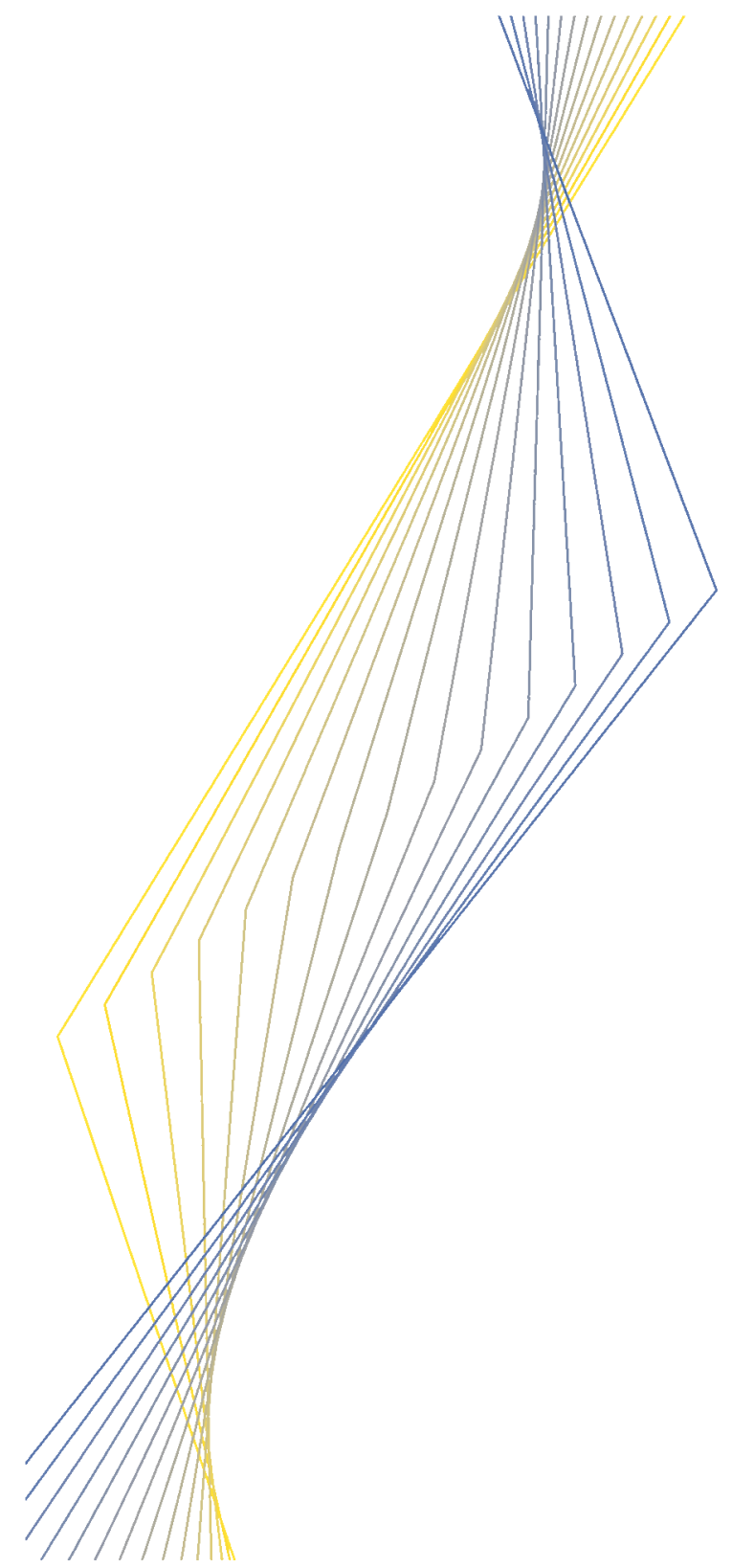

WORKING PAPER NO. 232

\author{
DESCRIBING THE FED'S \\ CONDUCT WITH TAYLOR \\ RULES: IS INTEREST RATE \\ SMOOTHING IMPORTANT?'
}

BY EFREM CASTELNUOVO ${ }^{2}$

\title{
May 2003
}

I I am grateful to Marie-Luce Bianne, Antonello D’Agostino, Carlo Favero, Marzio Galeotti, Dieter Gerdesmeier, Petra Gerlach-Kristen, Victor Lopez, Roberto Motto, Sergio Nicoletti-Altimari,Jorge Rodrigues, Barbara Roffia, Massimo Rostagno, Frank Smets, Paul Söderlind, Paolo Surico, Astrid Van Landschoot, an anonymous referee, and the participants at the European Central Bank/Monetary Policy Strategy Division Seminar for helpful comments and discussions. All remaining errors are mine. The hospitality of the European Central Bank, where much of this work was developed, is gratefully acknowledged. The opinions expressed herein are those of the author(s) and do not necessarily represent those of the European Central Bank. This paper can be downloaded without charge from http:II www.ecb. int or from the Social Science Research Network electronic library at: $h t t p: / / s s r n . c o m / a b s t r a c t \_i d=x x x x x x$

2 Bocconi University, Via Sarfatti 25 (c/0 Angela Baldassarre), 20136 Milano (Italy).E-mail: efrem.castelnuovo@uni-bocconi.it 
(C) European Central Bank, 2003

$\begin{array}{ll}\text { Address } & \text { Kaiserstrasse 29 } \\ & \text { D-603 I I Frankfurt am Main } \\ & \text { Germany } \\ & \text { Postfach } 1603 \text { I9 } \\ \text { Postal address } & \text { Germany Frankfurt am Main } \\ & +4969 \text { I344 } 0 \\ \text { Telephone } & \text { http://www.ecb.int } \\ \text { Internet } & +4969 \text { I344 } 6000 \\ \text { Fax } & 41 \text { I I44 ecb d } \\ \text { Telex } & \end{array}$

All rights reserved by the author/s.

Reproduction for educational and non-commercial purposes is permitted provided that the source is acknowledged. The views expressed in this paper do not necessarily reflect those of the European Central Bank.

ISSN I56I-08I0 (print)

ISSN I725-2806 (online) 


\section{Contents}

$\begin{array}{ll}\text { Abstract } & 4\end{array}$

Non-technical summary 5

$\begin{array}{lll}\text { I } & \text { Introduction } & 7\end{array}$

2 Rationalizing monetary policy gradualism 10

3 A direct test for partial adjustment versus serial correlation I3

$4 \quad$ PA versus SC:Alternative Taylor rate specifications $\quad$ I8

$\begin{array}{lll}5 & \text { Findings } & 20\end{array}$

6 A note on real time data analyses 29

$\begin{array}{lll}7 & \text { Conclusions } & 30\end{array}$

$\begin{array}{ll}\text { Technical appendix } & 32\end{array}$

$\begin{array}{ll}\text { Data appendix } & 36\end{array}$

$\begin{array}{ll}\text { References } & 38\end{array}$

European Central Bank working paper series $\quad 43$ 


\begin{abstract}
In this paper we estimate simple Taylor rules paying particular attention to interest rate smoothing. Following English, Nelson, and Sack (2002), we employ a model in first differences to gain some insights into the presence and significance of the degree of partial adjustment as opposed to a serially correlated policy shock. Moreover, we estimate a nested model to take into account both interest rate smoothing and serially correlated deviations from various Taylor rates prescriptions. Our findings suggest that the lagged interest rate enters the Taylor rule in its own right, and may very well coexist with (usually omitted) variables that relate to asymmetric preferences on the output gap, or financial market indicators. Therefore, while we cannot exclude that serially correlated policy shocks may play a role in describing the federal funds rate path, our results significantly support the importance of the lagged interest rate in Taylor-type models.
\end{abstract}

JEL classification system: E4, E5.

Keywords: Taylor rules, omitted variables, serial correlation, interest rate smoothing. 


\section{Non-technical summary}

Researchers involved in monetary policy analyses have been discussing the Taylor (1993) rule for a decade now. This simple rule, which links the inflation rate and a measure of output gap to the monetary policy rate, has turned out to be a satisfactory approximation of the various Central Banks' policy conduct all over the world. In fact, numerous researchers have focussed their attention on a modified Taylor rule, i.e. $i_{t}=(1-\rho) \tilde{i}_{t}+\rho i_{t-1}$, with $i_{t}$ identifying the short term nominal interest rate controlled by the Central Bank (CB henceforth), while $\tilde{i}_{t}$ is the original Taylor rule, whose implied policy rate level has been termed 'Taylor rate'. The modified Taylor rule suggests a partial, gradual adjustment to the Taylor rate after a shock has hit the economy. Notably, the estimated degree of partial adjustment $\rho$ has typically been very high, so suggesting the existence of interest rate smoothing, or monetary policy inertia.

Indeed, monetary policy-makers may have different sensible reasons to move the policy rate in a gradual fashion, e.g. financial markets' negative reaction to an excessive policy rate volatility, credibility, uncertainties, and learning. Nevertheless, Rudebusch (2002a) criticizes this conventional wisdom. In his stimulating contribution, he claims that the interest rate smoothing behavior at quarterly frequencies is just an illusion. By employing US data, Rudebusch tests for the Partial Adjustment (PA hereafter) hypothesis, i.e. the interest rate smoothing one, versus the Serial Correlation (SC) alternative, which relates to persistent deviations of the policy variable from the Taylor rate due to extraordinary episodes, such as shocks having a persistent effect on the economic system, or financial turmoils. In Rudebusch's work, a direct proof of the existence of this illusion, based on the estimation of a nested model in levels, turns out not to be definitive. Then, the author goes for an indirect proof. In a nutshell, his reasoning is the following: If the partial adjustment strategy had such a high importance in the policy rate setting, then rational agents should be capable of predicting future values of the quarterly rate with a high degree of precision. On the contrary, standard term structure regressions show how unpredictable the policy rate is over one quarter. Rudebusch takes this evidence to claim that the quarterly interest rate smoothing is just negligible, and that the observed persistency of the federal funds rate is mainly due to serially correlated deviations from the Taylor rate. As far as the Fed is concerned, such deviations could be due to particular circumstances, e.g. commodity price scares (1988-89 and 1994-95), credit crunches (1992-93), and financial crises (1998-99).

A reply to Rudebusch (2002a)'s conjecture is offered by English, Nelson, and Sack (2002). These authors, working on the first differences of the policy rate, 
show that it is possible to test directly the null of $\mathrm{SC}$ versus the alternative of PA. Their findings indicate a significant role for the latter; nevertheless, a nested model seems to be better suited for capturing the policy rate behavior.

In this paper we extend English, Nelson, and Sack (2002)'s analysis. In exploiting their modeling strategy, we consider a richer set of alternative Taylor rate definitions. To do so, we take into account diverse, possibly important omitted variables, so capturing the stimuli coming from Surico (2002) and GerlachKristen (2002). In particular, we assess the statistical relevance of regressors such as the quadratic gap (indicator of asymmetric preferences on the output gap level by a CB, as shown in Surico), and the credit spread (an indicator of financial stress, as discussed in Gerlach-Kristen).

Our results indicate that US data largely support the partial adjustment mechanism hypothesis. Indeed, if it is hard to rebut the importance of a serially correlated policy shock in a Taylor type scheme, it seems even harder to reject that of the lagged interest rate. Notably, this conclusion turns out to be quite robust across the different Taylor rates specifications we employed.

Indeed, credit crunches or financial crises represent shocks that may very well suggest serially correlated deviations with respect to the policy recommended by the Taylor rate; in this sense, we are sympathetic with Rudebusch (2002a)'s argument. Nevertheless, our estimates indicate that the lagged interest rate does play a key-role in a Taylor-type model. By contrast, the presence of a serially correlated policy shock, although often statistically relevant, does not seem to be sufficient in explaining the observed interest rate gradualism. Therefore, our results do not necessarily contradict Rudebusch (2002a)'s claim on the significance of a serially correlated error term in estimated Taylor rules, but strongly support English, Nelson, and Sack (2002)'s conclusion on the key-role played by the lagged depended variable in this type of policy functions.

Finally, our empirical findings seem to call for further research on nonstandard explanatory variables to be included into Taylor type regressions. Asymmetric policy preferences (Surico, 2002) and financial indicators (GerlachKristen, 2002) are surely worthy of further investigation from both a positive and a normative side, also in the light of some recent contributions on the relationship between asymmetric preferences and ex-ante average inflation bias (Cukierman and Muscatelli, 2002, Cukierman and Gerlach, 2003, and Surico, 2003), and on the importance of financial markets evolution for monetary policy decisions (Cecchetti, Genberg, and Wadhwani, 2002). 


\section{Introduction}

Researchers involved in monetary policy analyses have been discussing the Taylor (1993) rule for a decade now. This simple rule, which links the inflation rate and a measure of output gap to the monetary policy rate, has turned out to be a satisfactory approximation of the various Central Banks' policy conduct all over the world. In fact, numerous researchers have focussed their attention on a modified Taylor rule, i.e. $i_{t}=(1-\rho) \tilde{i}_{t}+\rho i_{t-1}$, with $i_{t}$ identifying the short term nominal interest rate controlled by the Central Bank (CB henceforth), while $\tilde{i}_{t}$ is the original Taylor rule, whose implied policy rate level has been termed 'Taylor rate'. The modified Taylor rule suggests a partial, gradual adjustment to the Taylor rate after a shock has hit the economy. Notably, the estimated degree of partial adjustment $\rho$ has typically been very high, so suggesting the existence of interest rate smoothing, or monetary policy inertia. ${ }^{1}$

Indeed, the literature has offered various sensible reasons to interpret the estimated policy gradualism. ${ }^{2}$ Nevertheless, Rudebusch (2002a) criticizes this conventional wisdom. In his stimulating contribution, he claims that the interest rate smoothing behavior at quarterly frequencies is just an illusion. By employing US data, Rudebusch tests for the Partial Adjustment (PA hereafter) hypothesis, i.e. the interest rate smoothing one, versus the Serial Correlation (SC) alternative, which relates to persistent deviations of the policy variable from the Taylor rate due to extraordinary episodes, such as shocks having a persistent effect on the economic system, or financial turmoils. In Rudebusch's work, a direct proof of the existence of this illusion, based on the estimation of a nested model in levels, turns out not to be definitive. ${ }^{3}$ Then, the author goes for an indirect proof. In a nutshell, his reasoning is the following: If the partial

\footnotetext{
${ }^{1}$ Clarida, Galí, and Gertler $(1999,2000)$ estimate such a partial adjustment degree with various specifications of the Taylor rule with US data, finding a magnitude $\simeq 0.8$. The same magnitude is found by Kozicki (1999), Amato and Laubach (1999), Domenéch, Ledo, and Taguas (2002). Estimates for some other industrialized countries are offered by Clarida, Galí, and Gertler (1998), Gerlach and Schnabel (2000), and Domenéch, Ledo, and Taguas (2002).

${ }^{2}$ Discussions concerning the interest rate smoothing issue may be found in Lowe and Ellis (1997), Goodhart (1999), Sack and Wieland (2000), Cecchetti (2000), and Srour (2001). In Section 2 we review some of the reasons why a CB may optimally implement a gradual path of its policy rate.

${ }^{3}$ High correlation in the Taylor rule's regressors, their dynamic endogeneity, small sample bias, and uncertainty about the appropriate arguments of the historical policy rate are among the motivations put forward by Rudebusch (2002a, pp. 1178-1179) to justify the lack of power regarding the PA vs. SC test constructed on his nested model.
} 
adjustment strategy had such a high importance in the policy rate setting, then rational agents should be capable of predicting future values of the quarterly rate with a high degree of precision. On the contrary, standard term structure regressions show how unpredictable the policy rate is over one quarter. Rudebusch takes this evidence to claim that the quarterly interest rate smoothing is just negligible, and that the observed persistency of the federal funds rate is mainly due to serially correlated deviations from the Taylor rate. As far as the Fed is concerned, such deviations could be due to particular circumstances, e.g. commodity price scares (1988-89 and 1994-95), credit crunches (1992-93), and financial crises (1998-99). ${ }^{4}$

Söderlind, Söderström, and Vredin (2002a, SSV henceforth) go a step further. By working with an AD-AS model à la Rudebusch (2002b), they show that with model consistent rational expectations on the interest rate change, the predictability of the latter increases as the PA parameter $\rho$ becomes larger. Importantly, SSV underline how a high $\rho$ is a necessary but not sufficient condition to effectively predict the policy rate variations. In fact, this predictability also comes from the high predictability of variables such as the inflation rate and the output gap level. ${ }^{5}$ SSV (2002a) also verify, with survey data and a small VAR model, that the predictability of the short term interest rate change is very low (as also shown in Rudebusch 2002a). Then, they conclude that a high degree of PA cannot coexist with a standard Taylor rate, given that the latter is composed of highly predictable variables, and this would indeed imply largely forecastable policy rate changes. In SSV (2002a)'s opinion, there might be an omitted variable problem in the Taylor (1993) rate $\tilde{i}_{t}$ definition. Notice that, to be consistent with a high degree of PA, this potentially missing variable should not be easily predictable, because otherwise it would not be compatible with the yield curve indirect test. ${ }^{6}$

A reply to Rudebusch (2002a)'s conjecture is offered by English, Nelson, and

\footnotetext{
${ }^{4}$ In fact, in drawing the conclusions of his paper, Rudebusch (2002a) acknowledges for the possibility of "[...] some intermediate case of partial adjustment, [...] along with some serially correlated shocks, that is not strictly rejected by the term structure evidence".

${ }^{5}$ When SSV (2002a) make the hypothesis that both inflation and output gap are white noise, they find that the larger the PA coefficient $\rho$, the less predictable future changes in the policy rate are. In this sense, the extreme case (i.e. $\rho \rightarrow 1 \Rightarrow \Delta i_{t} \rightarrow$ random walk) is illuminating.

${ }^{6}$ This last statement finds its basis on the Rational Expectation Hypothesis. In fact, most of the empirical literature reject the expectations model of the term structure. As an exception on this point, see Favero (2002).
} 
Sack (2002, ENS hereafter). These authors, working on the first differences of the policy rate, show that it is possible to test directly the null of SC versus the alternative of PA. Their findings indicate a significant role for the latter; nevertheless, a nested model seems to be better suited for capturing the policy rate behavior. Gerlach-Kristen (2002) also comments on Rudebusch (2002a)'s contribution. In her paper she investigates the role of omitted variables in the estimation of the Taylor rule. By using Kalman filtering, she finds that both PA and a financial indicator such as the risk-premium are important components in replicating the observed federal funds rate path.

In this paper we extend ENS's analysis. In exploiting their modeling strategy, we consider a richer set of alternative Taylor rate definitions. To do so, we take into account diverse, possibly important omitted variables, so capturing the stimuli coming from Surico (2002) and Gerlach-Kristen (2002). In particular, we assess the statistical relevance of regressors such as the quadratic gap (indicator of asymmetric preferences on the output gap level by a $\mathrm{CB}$, as shown in Surico), and the credit spread (an indicator of financial stress, as discussed in Gerlach-Kristen).

Our results indicate that US data largely support the partial adjustment mechanism hypothesis. Indeed, if it is hard to rebut the importance of a serially correlated policy shock in a Taylor type scheme, it seems even harder to reject that of the lagged interest rate. Notably, this conclusion turns out to be quite robust across the different Taylor rates specifications we employed.

The structure of the paper reads as follows. In Section 2 we discuss some reasons why a CB should optimally implement a gradual policy. Section 3 explains Rudebusch (2002a)'s opinion regarding the conventional wisdom on monetary policy inertia. In the same Section, the identification problem affecting a test performed with a model in levels is underlined, and English, Nelson, and Sack (2002)'s alternative strategy is described. In Section 4 we present the alternative specifications of the Taylor rate we employ in our analysis, while in the following Section we discuss our findings, that confirm that the lagged interest rate plays a role per se in the description of the American monetary policy conduct in the last two decades. Then, in Section 6 we make a qualitative point regarding the 'real time versus revised data' discussion which has been very lively in this literature in the past few years. Section 7 concludes. A Technical appendix on how 
to solve a Rational Expectations model with a simple Taylor rule is provided, together with a Data appendix illustrating the sources of the time-series and the construction of the variables employed in our analysis. References follow.

\section{Rationalizing monetary policy gradualism}

The issue of dynamics is important from a policy perspective. In fact, in the last two decades we have observed an improvement of the inflation-output gap trade-off in many industrialized countries. Part of this improvement is surely attributable to better monetary-policy management, as remarked by Cecchetti, Flores Lagunes, and Krause (2001) and Favero and Rovelli (2003). ${ }^{7}$ In general, it is important to understand the determinants of this successful management, in order to possibly replicate this success in presence of future, similar macroeconomic conditions. Among these determinants, has monetary policy gradualism played an important role? Recent research in monetary policy has indicated various possible reasons for a $\mathrm{CB}$ to move in a moderate manner its policy rate. In this section, we quickly discuss some of them.

\section{Private Sector Expectations}

It is well known that, in absence of a commitment technology, the $\mathrm{CB}$ is incapable of manipulating private sector's expectations, due to the timeinconsistency feature of its promises of fighting inflation which renders these promises non-credible (Kydland and Prescott, 1977). Indeed, this leads the Society to an inferior level of efficiency with respect to that coming from a solution under commitment, as explained by Rogoff (1985). In studying this problem, Woodford (1999) suggests the possibility to reduce the gap existing between these two solutions. He proposes to induce the $\mathrm{CB}$ to target an interest rate smoothing argument, i.e. to limit the volatility of the interest rate change. In doing so, an optimally behaving $\mathrm{CB}$ would implement an inertial interest rate close to the one that it would set under the commitment scenario. The inertia implied by the interest rate smoothing targeting would have an effect on the economic system through private sector expectations as if the $\mathrm{CB}$ owned a commitment technology.

\footnotetext{
${ }^{7}$ The same authors underline that the improved inflation-output gap trade-off has probably not been uniquely caused by a better monetary policy management. In fact, there is a certain evidence of a change in monetary policy preferences, and of more favourable sequences of supply shocks. Still, better monetary policy management seems to have been quite significant.
} 


\section{Parameter Uncertainty}

In the real world, monetary policy-making is an exercise undertaken in an uncertain environment (Goodhart, 1999). Indeed, the CB does face a lack of information concerning the monetary transmission mechanism. One of these uncertainties regard the parameters linking the aggregates which compose the relevant economic environment the $\mathrm{CB}$ is interested in. The first impacting contribution in this context was Brainard (1967)'s. His story is simple: A policy-maker who is partially ignorant relative to the key-parameters of the economy may implement prudent monetary actions when responding to shocks, since in this way it will reduce the 'uncertainty cost', i.e. the possibility of inducing a large volatility in the economy due to a misinterpretation of the monetary transmission mechanism. ${ }^{8}$ Söderström (1999) and Sack (2000) empirically demonstrate that in an optimal control context with VAR representations of the economic dynamics it is possible to replicate fairly well the federal funds rate path by taking into account parameter uncertainty. ${ }^{9}$

\section{Model Uncertainty}

McCallum (1999) sustains that a good policy rule is the one that is capable of performing well across many different models. In fact, the CB's uncertainty is likely to concern the formalization of the whole economic framework. Empirical contributions by Favero and Milani (2001) and Castelnuovo and Surico (2003), conducted with a class of linear backward looking models, show that considering many diverse models may lead the CB to implement a gradual, optimal monetary policy. Indeed, model uncertainty may be an important component in tracking the CB's historical policy rate path.

\footnotetext{
${ }^{8}$ It should be noticed that in his contribution Brainard (1967) points out how this result is driven by the low covariance existing between the policy instrument and the state variables; indeed, a high covariance could overturn the result.

${ }^{9}$ However, there is not yet a complete agreement on the link between this type of uncertainty and the optimal CB's behavior. In fact, Söderström (2002) suggests that uncertainty related to the persistence of the inflation mechanism may induce CBs to implement an aggressive strategy to reduce the uncertainty about the future development of inflation. Robust-control oriented works, such as those by Sargent (1999) and Onatski and Stock (2002) show that the best possible reaction of the CB to the worst-scenario drawn by the Nature is an aggressive monetary action. Finally, with the use of small scale models and focusing just on a few keyparameters, Estrella and Mishkin (1999), Peersman and Smets (1999), and Rudebusch (2001) claim that parameter uncertainty seems not to have an important impact on the optimally determined feedback rule coefficients.
} 


\section{Learning}

Does learning enhance gradualism? Sack (1998) shows how a CB that periodically refines his estimates of the key-parameters linking the variables of interest in a given framework may choose to act gradually. This result is due to the stochastic features of the economic dynamics, that render particularly informative the most recent observations. As a result, the Fed faces more uncertainty about the reaction of the economy as it moves the funds rate away from its recent levels. ${ }^{10}$

\section{Data Uncertainty - Measurement Error}

Orphanides (1998) offers an important contribution regarding the noise affecting the data. His point is intuitive: Monetary authorities should respond to shocks gradually, because it is difficult to understand if the one under consideration is a pure economic shock, or just a measurement error (or a mix between the two). Indeed, when simple rules à la Taylor (1993) are taken into account, the increase in volatility caused by measurement errors matters. ${ }^{11}$

\section{Financial Markets Reaction}

A cautious monetary policy may also reflect the attention that the CB poses to the reactions that financial markets exert after a monetary policy decision has been implemented. In fact, Goodfriend (1991)'s claim is that markets could over-react to a series of swings of the reference nominal rate, so negatively affecting the real side of the economy. ${ }^{12}$

\footnotetext{
${ }^{10}$ However, Sack (1998) himself and Wieland (2000) point out that there exist a dynamic trade-off between gradualism and learning, i.e. it may become optimal in a dynamic set-up to implement an aggressive policy in order to learn how the economy react to new, different monetary policy shocks. Indeed, an aggressive policy might speed up the learning process. Nevertheless, this approach, termed experimentation (see Bertocchi and Spagat, 1993, and Caplin and Leahy, 1996), do not seem to be supported by Policy Makers' official declarations. In fact, it is worth to mention a comment by a former Vice-Chairman of the Fed, Alan Blinder (1998, p.11): "You don't conduct experiments on a real economy solely to sharpen your econometric estimates".

${ }^{11}$ Notice that this does not hold if we consider the policy rule coming from first principles in a linear-quadratic context. For a formal demonstration of this application of the certainty equivalence principle, see Ljungqvist and Sargent (2000, chapter 4).

12 An interesting point tackling this view is provided by Cecchetti (2000), who underlines how large jumps in the policy instrument could be disruptive only if financial markets are relatively certain that it will never happen. If market participants expect that new information can precipitate large and sudden interest rate changes, then they will defend themselves by building up institutions in order to avoid any negative consequence. In his opinion, the only reason that people believe smooth interest rates enhance financial stability is because interest rate has been smooth up to now.
} 


\section{A direct test for partial adjustment versus se- rial correlation}

Rudebusch (2002a) performs an indirect test on the importance of PA versus SC. He exploits standard term structure regressions in order to show that the predictive power of the market regarding future changes of the short-term interest rate over a quarter is very low. ${ }^{13}$ Then, Rudebusch's claim is that interest rate levels cannot be explained by a large degree of PA, because this would lead to a easily forecastable variation of the policy rate. In fact, Rudebusch (2002a) also tries to test directly the non-significance of the PA hypothesis. Formally, he builds up an empirical model nesting the PA specification

$$
i_{t}=(1-\rho) \tilde{i}_{t}+\rho i_{t-1}+\eta_{t}
$$

$\left(\eta_{t}=\right.$ white noise process $)$ with the SC specification

$$
i_{t}=\tilde{i}_{t}+\varepsilon_{t}, \varepsilon_{t}=\rho_{\varepsilon} \varepsilon_{t-1}+\eta_{t}
$$

$\left(\varepsilon_{t}=\mathrm{AR}(1)\right.$ process $) .{ }^{14}$ The nested model reads as follows:

$$
i_{t}=(1-\rho) \tilde{i}_{t}+\rho i_{t-1}+\varepsilon_{t}, \varepsilon_{t}=\rho_{\varepsilon} \varepsilon_{t-1}+\eta_{t}
$$

As far as the Taylor rate $\tilde{i}_{t}$ is concerned, Rudebusch concentrates on two different formalizations. The first one is the original Taylor (1993) rate, which reads as follows:

$$
\tilde{i}_{t}=c+b_{\pi} \bar{\pi}_{t}+b_{y} y_{t}
$$

${ }^{13}$ The standard term structure regressions run by Rudebusch (2002a) refer to the following model: $\Delta i_{t+j}=\delta+\gamma E_{t} \Delta i_{t+j}+\psi_{t+j}^{j}$, for $j \geqslant 1$.

${ }^{14}$ We performed some econometric exercises in order to measure the order of serial correlation featuring the residuals of simple backward and forward looking Taylor rules without smoothing. Our findings suggest that an $\mathrm{AR}(1)$ process is a good approximation of the policy shocks behavior. We did not include these figures in the paper for sake of brevity; however, these figures are available upon request. 
where $c$ is a constant, $\bar{\pi}_{t}=$ four quarter average inflation rate, and $y_{t}=$ output gap. ${ }^{15}$ This is a natural benchmark definition of the Taylor rate. ${ }^{16}$ A different specification of the Tayor rate has been popularized by CGG $(1998,1999,2000)$. These authors have underlined the importance for the CB to adjust the policy rate with respect to future, forecast movements of both inflation and output gap. Their idea finds its rationale in the lags affecting the monetary policy transmission. ${ }^{17}$ Their definition of the Taylor rate can be captured by the following formalization:

$$
\tilde{i}_{t}=c+b_{\pi} E_{t-1} \bar{\pi}_{t+4}+b_{y} E_{t-1} y_{t}
$$

Then, by working with equation (3) and - alternatively - (4) or (5), Rudebusch (2002a) tests first for the significance of the PA, then for that on SC. The test suggests rejection neither for PA nor for SC. Why so? Rudebusch explains that there is an identification problem at this point. In fact, it is very difficult to distinguish between the dynamics deriving from a PA mechanism and those induced by a SC specification when observing at the realizations of the policy rate, since both these processes (which are very different from an economic standpoint) may induce the same (or similar) path of the policy rate. ${ }^{18}$

To better understand this identification problem, we construct two counterfactual policy rates, the first one just driven by a PA mechanism, and the second one by SC. To do so, we employ an AD-AS model à la Rudebusch (2002b). The Phillips curve reads as follows:

$$
\pi_{t+1}=\mu_{\pi} E_{t} \bar{\pi}_{t+4}+\left(1-\mu_{\pi}\right) \sum_{j=1}^{4} \alpha_{\pi j} \pi_{t-j+1}+\alpha_{y} y_{t}+\varepsilon_{t+1}^{\pi}
$$

\footnotetext{
${ }^{15}$ The variables definition may be found in the Data appendix. About the Taylor rate definitions, notice that they do not have any error term, since the policy deviations with respect to the suggested rate are represented in our set up by the vector $\eta_{t}$.

${ }^{16}$ In Taylor (1993), the policy rule reads as follows: $i_{t}=\bar{\pi}_{t}+0.5 y_{t}+0.5\left(\bar{\pi}_{t}-\pi^{*}\right)+r^{*}$, with $\pi^{*}=r^{*}=2 \%$. Then, the constant $c$ in the various Taylor rates is a linear convolution of the inflation target $\pi^{*}$ and the real interest rate of equilibrium $r^{*}$, i.e. $r^{*}-\left(b_{\pi}-1\right) \pi^{*}$. Neither in Rudebusch (2002a)'s nor in our study the focus is the one of assessing these elements. For investigations concentrating on these components, see Judd and Rudebusch (1998), and Domenéch, Ledo, and Taguas (2002).

${ }^{17} \mathrm{An}$ already 'classical' reference for the dynamics of the monetary policy transmission is Christiano, Eichembaum, and Evans (1998).

${ }^{18}$ See Rudebusch (2002a)'s discussion at page 1178.
} 
while the dynamic IS equation is

$$
\begin{aligned}
y_{t+1}= & \mu_{y} E_{t} y_{t+2}+\left(1-\mu_{y}\right) \sum_{j=1}^{2} \beta_{y j} y_{t-j+1} \\
& -\mu_{r} \beta_{r}\left(i_{t}-E_{t} \bar{\pi}_{t+4}\right)-\left(1-\mu_{r}\right) \beta_{r}\left(\bar{i}_{t}-\bar{\pi}_{t}\right)+\varepsilon_{t+1}^{y}
\end{aligned}
$$

where $\pi_{t}$ is the four-quarter inflation rate, $y_{t}$ is the output gap, $i_{t}$ is the short term nominal interest rate, and $\bar{x}_{t}=\sum_{s=0}^{3} x_{t-s}, x_{t}$ being either inflation or the policy rate. As shown by Söderlind, Söderström, and Vredin (2002b), this stylized representation of the economy is capable of replicating fairly well the observed dynamics of the variables here considered. By using the system of equations (3), (4), (6), and (7), we can build two counterfactual policy rates whose explanatory variables are fully endogenously determined by the system itself. ${ }^{19}$ In constructing these rates, we keep fixed parameters such as $\alpha_{s}, \beta_{s}, \mu_{s}$, and the coefficients of the original Taylor rate $b_{s}$. The estimated coefficients are presented in Table 1. Moreover, we impose $\mu_{\pi}=0.1, \mu_{y}=0.3$, and $\mu_{r}=1$, as in Castelnuovo (2003).

Then, we just use two different pairs of calibrated values $\left(\rho, \rho_{\varepsilon}\right)$, in order to plot the two counterfactual rates. ${ }^{20}$ We use the pair $(0.7,0.0)$ to identify the PA specification, while $(0.0,0.9)$ for the SC one. Figure 1, which also includes the actual federal funds rate, is the outcome of our effort.

As it is possible to see, the three rates are roughly tracking the same pattern. In fact, the similarities regarding a few descriptive statistics, presented in Table 2, reinforce the idea that in assessing the existence and importance of the PA mechanism versus SC process we cannot rely on the sole estimation of the encompassing model (1)-(2). Moreover, small-sample limitations may very much imply large parameter uncertainty. Indeed, a definitive choice between PA and SC seems to be difficult in this context. Therefore, a sharp 'either-or' test must rely on an alternative, different econometric model.

\footnotetext{
${ }^{19}$ In the Technical appendix we describe how to implement this exercise.

${ }^{20}$ Given all the other parameters of the model, as well as the estimated shocks affecting inflation, output gap, and the monetary policy rule, we calibrated the coefficients $\rho$ and $\rho_{\varepsilon}$ in order to minimize the squared deviations of each simulated rate with respect to the actual one.
} 


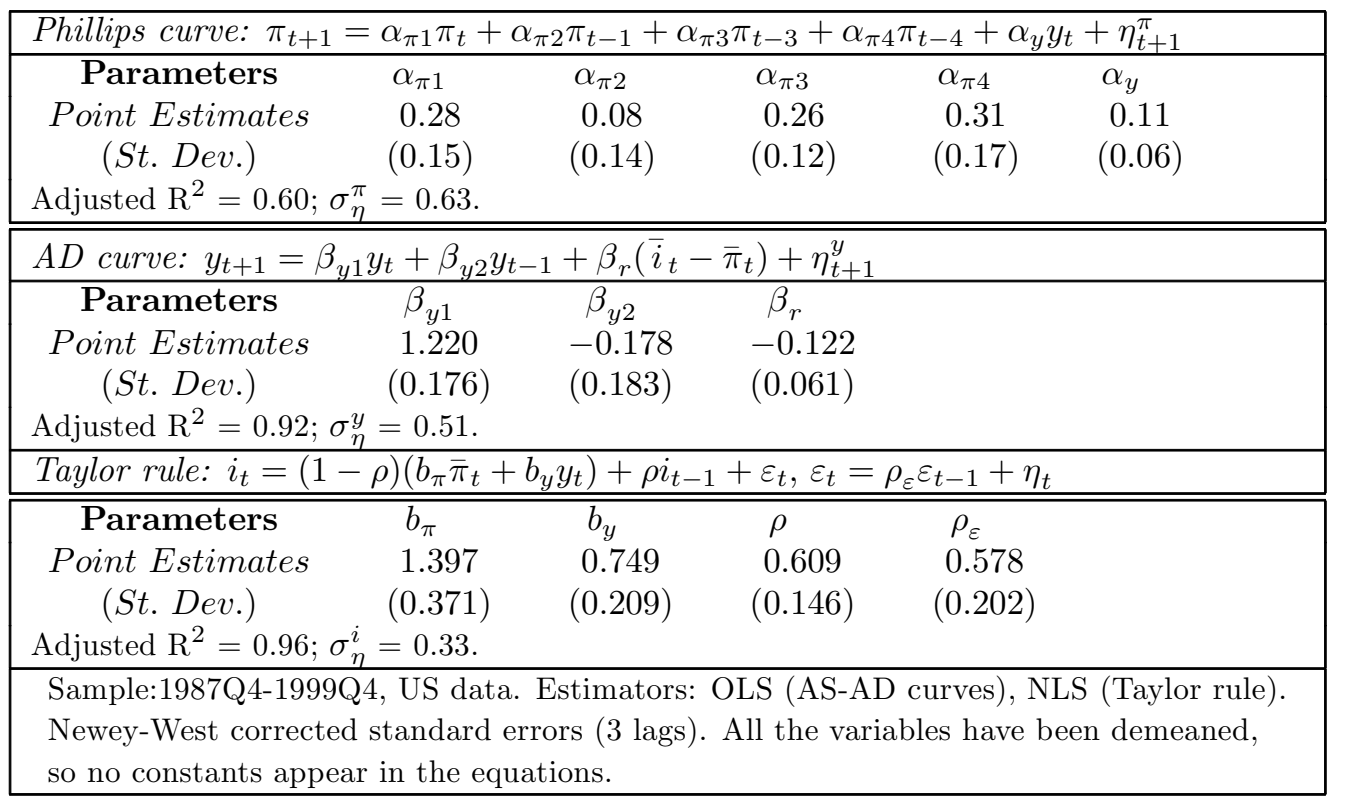

Table 1: Estimates of the AD-AS-Taylor rule model

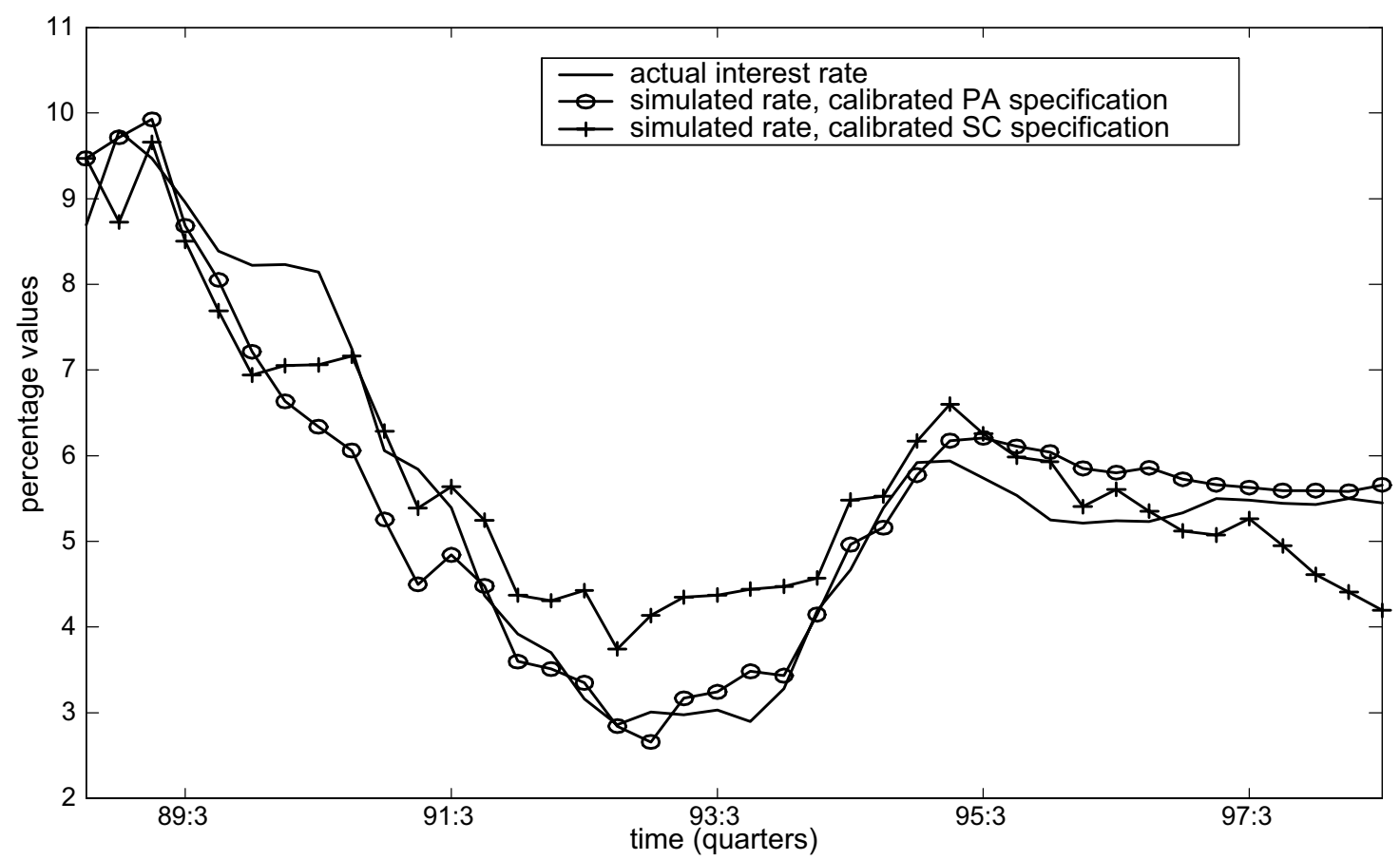

Figure 1: Actual, simulated PA, and simulated SC policy rates 


\begin{tabular}{|c||ccc|}
\hline Policy rates & Mean & St. Dev. $\left(i_{t}\right)$ & St. Dev. $\left(\Delta i_{t}\right)$ \\
\hline \hline Actual & 5.52 & 1.82 & 0.46 \\
PA specification & 5.55 & 1.81 & 0.45 \\
SC specification & 5.75 & 1.49 & 0.48 \\
\hline Simulated rates constructed by using an AD-AS-Taylor rule representation \\
of the economy. Partial Adjustment mechanism coefficients: $\rho=0.7 ; \rho_{\varepsilon}=0.0$. SC \\
specification: $\rho=0.0 ; \rho_{\varepsilon}=0.9$. Estimates of the coefficients $\alpha_{s}, \beta_{s}$, and $b_{s}$ are re- \\
ported in Table 1. The values of the parameters $\mu_{s}$ are $\mu_{\pi}=0.1, \mu_{y}=0.3, \mu_{r}=1$, as \\
calibrated in Castelnuovo (2003).
\end{tabular}

Table 2: Policy rates descriptive statistics

The importance of the contribution by ENS (2002) relates exactly to this identification issue. They notice that while the two different specifications (1) and (2) have similar implications for the behavior of the interest rate level, this similarity does not hold anymore when first differences are taken into account. To see why, consider equation (1). Making some algebra, it is possible to arrive at the following formulation:

$$
\Delta i_{t}=(1-\rho) \Delta \tilde{i}_{t}+(1-\rho)\left(\tilde{i}_{t-1}-i_{t-1}\right)+\eta_{t}
$$

Differently, the SC specification (2) leads to this alternative equation:

$$
\Delta i_{t}=\Delta \tilde{i}_{t}+\left(1-\rho_{\varepsilon}\right)\left(\tilde{i}_{t-1}-i_{t-1}\right)+\eta_{t}
$$

The latter equation sheds some light on the implications of the SC engine. Here, variations of the Taylor-rate cause an immediate and full reaction of the policy rate change; by contrast, an inertial adjustment is present in equation (8) via the coefficient $(1-\rho)$. Then, it is possible to build up a direct test on the PA versus SC hypotheses. ENS estimate the empirical model

$$
\Delta i_{t}=\gamma_{2} \Delta \tilde{i}_{t}+\gamma_{3}\left(\tilde{i}_{t-1}-i_{t-1}\right)+\eta_{t}
$$

and test the null hypothesis

$$
H 0_{S C}: \gamma_{2}=1
$$


Under the null (11), the SC specification holds true. ENS verify that the null is undoubtedly rejected, and conclude that the SC model is not sufficient to replicate the observed federal funds rate persistence. Then, they check if the PA model alone is sufficient to replicate the policy rate pattern, and test the null

$$
H 0_{P A}: \gamma_{2}=\gamma_{3}
$$

In fact, there is no reason to believe that only one of the two hypotheses holds. Indeed, both PA and SC could be important in fitting the actual monetary policy rate. ENS build up and test a nested structure equivalent to (3), finding that both PA and SC are supported by the data. So, even in the presence of a SC component, the data seem not to discard the PA specification.

To summarize, ENS (2002) tackle the identification problem raised by Rudebusch (2002a) and succeed in constructing a test to directly support the importance of the PA hypothesis in describing the Fed's decisions during Greenspan's regime.

In this paper we extend ENS's contribution. When testing for the PA versus SC hypotheses, we allow for different specifications of the Taylor rate. In particular, we consider (usually omitted, but potentially important) variables such as the quadratic gap (indicator of asymmetric preferences on the output gap level, see Surico, 2002) or the credit spread (computed as the difference between a risky investment, i.e. the Moody's BAA yield on corporate bonds, and the 10-year government bond yield). We do so to check if these variables are capable of (at least partly) offsetting the high degree of PA recorded so far in the literature. In the next Section we fully describe our approach, and we comment on our findings.

\section{PA versus SC: Alternative Taylor rate speci- fications}

Before exploiting the estimation strategy set up by ENS (2002), we have to specify the Taylor rate $\tilde{i}_{t}$. Naturally, we consider the already commented feedback rules (4) and (5). However, as mentioned above, Rudebusch (2002a) suspects that the omission of serially correlated variables could potentially be the cause 
of the estimated high degree of PA. To also check for this, we enrich the original specifications (4) and (5) by adding a third regressor, as follows:

$$
\widetilde{i}_{t}=c+b_{\pi} \bar{\pi}_{t}+b_{y} y_{t}+b_{z} z_{t}
$$

and

$$
\tilde{i}_{t}=c+b_{\pi} E_{t-1} \bar{\pi}_{t+4}+b_{y} E_{t-1} y_{t}+b_{z} E_{t-1} z_{t}
$$

In our exercise, the regressor $z_{t}$ plays different roles. A variable that we want to control for is a quadratic transformation of the output gap level, i.e. $z_{t}$ $=y_{t}^{2}$, that captures asymmetric concern by the $\mathrm{CB}$ as far as deviations of the realized output with respect to the potential one are concerned. In doing so we feel inspired by recent works on CBs' asymmetric preferences, which imply a non-quadratic representation of their loss function. ${ }^{21}$ Many normative analyses conducted so far have relied on a quadratic formalization of the CB's penalty function. Indeed, apart from analytical tractability, there does not seem to be an obvious reason why a $\mathrm{CB}$ should symmetrically target the output gap measure (Blinder, 1997; Goodhart, 1999; Mayer, 2002). A Taylor rule with a quadratic gap as additional explanatory variable does encompass an asymmetric preference by the CB on output gap realizations. In particular, Surico (2002) shows that, if $b_{z}$ is statistically relevant and assumes a negative sign, then we may think of that as an indicator of more moderate policy responses in booms than in recessions.

We also want to control for the impact of financial market conditions. This seems to be an interesting check, given the lively discussion that has been taking place for a couple of years now on the attention that the CB should pose on financial markets. ${ }^{22}$ In particular, $z$ will be a measure of credit spread, i.e. the

\footnotetext{
${ }^{21}$ Along with Surico (2002), Cukierman and Muscatelli (2002) and Cukierman and Gerlagh (2003) have performed empirical endeavours on this issue. See also the references quoted in those papers.

${ }^{22}$ See for example the two stimulating and opposite views by Bernanke and Gertler (2001) and Cecchetti, Genberg, and Wadhwani (2002), and the citations therein. Notice that in their discussion the key variable taken into account as indicator of the financial markets conditions is the asset prices misalignements. Instead, in our empirical exercise we work with the credit spread, as defined in Gerlach-Kristen (2002).
} 
spread between corporate and treasury bonds. Guha and Hiris (2002) empirically demonstrate that this is a counter-cyclical, leading indicator of macroeconomic business conditions. An economic rationale for the causality link going from the spread to the business cycle is the credit channel of monetary policy transmission, formalized first by Bernanke and Blinder (1988), and updated by Bernanke and Gertler (1995) and Bernanke, Gertler, and Gilchrist (1996). ${ }^{23}$ Given its properties as a counter-cyclical, leading indicator of the business cycle, a significant and negative sign associated to $b_{z}$ would make us conjecture that the credit spread has played an important role in Greenspan's feedback rule.

Our exercise aims at testing the PA versus SC hypotheses. To do so, we first estimate equation (10) with the Taylor rate alternatively specified as (4), (5), (13), and (14). As a second step, we estimate the nested model (3), once more considering all the above indicated Taylor rate specifications, in order to assess if there is trace of a 'joint significance'. Since we want to compare our results with Rudebusch (2002a)'s, we employ his sample choice, i.e. 1987Q4-1999Q4. We adopt a Non-linear Least Square estimator in backward looking models (i.e. when (4) and (13) are considered), while GMM when (5) and (14) are taken into account. A robustness check on our GMM estimates, performed on the basis of Survey data, is also presented. Our results and a discussion follow.

\section{Findings}

We now present our results. Table 3 collects our findings regarding the PA versus SC test run with a backward looking framework. ${ }^{24}$ A few remarks are

\footnotetext{
${ }^{23}$ In brief, the credit channel works as follows. Suppose to be in a good moment for the economy. Current income is high, and expectations are positive. Then, investors are willing to buy profitable shares; as a consequence, asset prices raise. This improves the situation of the firms' balance sheets, and imply an easier access to banks' loans, on average. The larger collateral available guarantees also more favourable rates on these loans for the firms. As a consequence, firms need to raise less funds via their corporate bonds, then returns on those bonds will be lower. This tightens the credit spread, and triggers (with some lags) the economic boost. However, at some point this boom in economic activities will become inflationary. The $\mathrm{CB}$ will react by raising the real interest rates, so profits and expectations will turn down. This implies a reduction of the asset prices, so of the collateral that firms may provide to banks. This will induce banks to augment their returns on loans, so firms will have to switch toward other financial channels, e.g. corporate bonds. The increase in the latter's yields will enlarge the credit spread, while the cycle starts declining.

${ }^{24} \mathrm{~A}$ note of cautious in evaluating our findings is needed. Our econometric estimates rely on the assumption of stationarity of the series at hand. In fact, as far as some of the series employed here are concerned, the null of unit root turns out to be very hard to reject when a standard augmented Dickey-Fuller test is employed. However, it is well known that the
} 
worthwhile. First of all, the values and the significance of the parameters $b_{\pi}$ and $b_{y}$ seem to be robust across specifications. In particular, the elasticity of the policy rate with respect to inflation is statistically in line with the value posed by Taylor (1993). ${ }^{25}$ Our point-estimates for $b_{y}$ are slightly larger than the value proposed by Taylor, but are roughly in line with those obtained by Judd and Rudebusch (1998), Kozicki (1999), Amato and Laubach (1999), and Rudebusch (2002a). Moreover, the parameter $b_{z}$ is statistically significant and has got the expected sign both in the case of asymmetric preferences and in the case of financial stress. Indeed, it seems possible to conjecture that Greenspan has behaved asymmetrically when facing positive and negative deviations of the real gross domestic product with respect to its stochastic trend; in this sense, we share Surico (2002)'s opinion. ${ }^{26}$ Moreover, indications coming from the financial market are statistically important for replicating the observed federal funds rate in the analyzed sample, so confirming results reached by GerlachKristen (2002). ${ }^{27}$

According to the $\bar{R}^{2}$ statistic, the descriptive power of all the models employed seems to be high. For our purposes, the most important row of Table 3 is the one where we collect all the p-values concerning the Wald test on the null (11). Robustly enough, the null is rejected at the $99 \%$ confidence level for all the three cases under investigation, so discarding SC as the unique ex-post descriptive mechanism of the federal funds rate path. By contrast, the null (12) is not rejected, even if the p-values corresponding to the models 'Standard Taylor' and 'Credit Spread' are not overwhelming on average. However, our findings

\footnotetext{
Dickey-Fuller test is not very reliable in short sample analyses.

${ }^{25}$ In fact, a standard Wald test cannot reject the restriction $b_{\pi}=1.5$ for none of the estimated backward looking Taylor rules. Nevertheless, a bit of cautiousness is necessary here, given the large estimated standard deviations, probably due to the small sample at hand.

${ }^{26}$ By constrast, Kim, Osborn, and Sensier (2002) apply a non-parametric technique to the CB's policy function, and cannot reject the null of linearity for the feedback rules they estimate for the post-Volcker era. Apart from the difference in the technique exploited, these authors concentrate on the sample 1979Q3-2000Q4, while we focus our attention on Greenspan's regime.

${ }^{27}$ Notice that there might be an endogeneity problem here. In fact, variations of the dependent variable (short term interest rate) are likely to influence all the term structure of interest rates, so also the long term rates featuring the regressor (credit spread). We think that the timing of this feedback still preserves our estimates from the unconsistency threat. Moreover, the sign of the credit spread estimated coefficient is in line with our expectations.
} 


\begin{tabular}{|c|c|c|c|}
\hline $\begin{array}{c}\text { Taylor rate } \\
\text { specification }\end{array}$ & $\begin{array}{c}\text { Standard } \\
\text { Taylor }\end{array}$ & $\begin{array}{l}\text { Asymmetric } \\
\text { preferences }\end{array}$ & $\begin{array}{l}\text { Credit } \\
\text { spread }\end{array}$ \\
\hline $\begin{array}{l}b_{\pi} \\
\end{array}$ & $\begin{array}{c}1.508^{* *} \\
(0.405)\end{array}$ & $\begin{array}{c}1.438^{* *} \\
\end{array}$ & $1.363^{* *}$ \\
\hline$b_{y}$ & $0.864^{* *}$ & $0.696^{* *}$ & $0.826^{* *}$ \\
\hline$h$ & $(0.195)$ & $(0.135)$ & $(0.075)$ \\
\hline$b_{z}$ & & $\begin{array}{c}-0.224^{* *} \\
(0.075)\end{array}$ & $\begin{array}{c}-2.611^{* *} \\
(0.531)\end{array}$ \\
\hline$\gamma_{2}$ & $\begin{array}{c}0.440^{* *} \\
(0.167)\end{array}$ & $\begin{array}{c}0.332^{* *} \\
(0.151)\end{array}$ & $\begin{array}{c}0.392^{* *} \\
(0.071)\end{array}$ \\
\hline$\gamma_{3}$ & $\begin{array}{c}0.197^{* *} \\
(0.070)\end{array}$ & $\begin{array}{c}0.301^{* *} \\
(0.057)\end{array}$ & $\begin{array}{c}0.290^{* *} \\
(0.073)\end{array}$ \\
\hline $\bar{R}^{2}$ & 0.954 & 0.965 & 0.979 \\
\hline$H_{0}: \gamma_{2}=1$ & $0.002^{* *}$ & $0.000^{* *}$ & $0.000^{* *}$ \\
\hline $\begin{array}{c}(F-\text { test }, p-\text { value }) \\
H_{0}: \gamma_{2}=\gamma_{3} \\
(F-\text { test }, p-\text { value })\end{array}$ & 0.186 & 0.841 & 0.417 \\
\hline \multicolumn{4}{|c|}{$\begin{array}{l}{ }^{*}=95 \% /^{* *}=99 \% \text { rejection of the null hyp. Estimated model: } \\
\Delta \mathrm{i}_{t}=\gamma_{2}\left(\mathrm{~b}_{\pi} \Delta \bar{\pi}_{t}+\mathrm{b}_{y} \Delta y_{t}+\mathrm{b}_{z} \Delta \mathrm{z}_{t}\right)+\gamma_{3}\left(\mathrm{c}+\mathrm{b}_{\pi} \bar{\pi}_{t-1}+\mathrm{b}_{y} y_{t-1}+\mathrm{b}_{z} \mathrm{z}_{t-1}-\mathrm{i}_{t-1}\right)+\eta_{t} \\
\mathrm{z}_{t}=y_{t}^{2} \text { (Asymmetric preferences); } \mathrm{z}_{t}=\text { spread (Credit spread). Estimates } \\
\text { performed via NLS estimator. Newey-West correction (3 lags) applied to } \\
\text { the standard errors (reported in brackets). } \\
\text { c omitted for brevity. } \bar{R} \text { refers to the level of the federal funds rate. }\end{array}$} \\
\hline
\end{tabular}

Table 3: Test for PA versus SC: Backward Looking Taylor Rules

tend to support ENS (2002)'s, and cast some doubts on Rudebusch (2002a)'s position.

In Table 4 we place our estimates obtained by working on forward looking Taylor rules. From a qualitative viewpoint, these figures tend to confirm those got with the backward looking models. In fact, all the estimated coefficients are statistically significant, and have the expected sign. The Taylor principle is not rejected, and this is a robust finding across rules. The output gap coefficient turns out to be lower when omitted variables are considered, signalling an upward bias in the estimated coefficient for the 'Standard Specification' model. Interestingly, the point estimates for the additional regressor are larger when forward looking rules are considered, while the estimated coefficients attached to the expected inflation rate are smaller. This might suggest that if a CB is targeting a forecast inflation rate then the importance of potentially important leading indicators such as the squared gap or the credit spread rises. ${ }^{28}$

\footnotetext{
${ }^{28}$ Notice that the J-statistics (p-values) largely confirm the goodness of our instrument choice. However, the number of overidentifying restrictions in the estimations we undertook is high, and might induce biases (Staiger and Stock, 1997). To check for the robustness of our
} 
When looking at our testable restrictions, the null (11) of pure SC process is strongly rejected, very much as in the backward looking case. Nevertheless, with the forward looking formulation also the null (12) is rejected in two cases out of three, so implying that the PA process per se has got hard time in fully describing the policy rate path in the last 15 years. This leads us to also estimate the encompassing model (3) in order to assess if the PA and SC hypotheses are jointly important from a positive standpoint.

Our results are presented in Table 5. First of all, the significance of all the regressors in the Taylor rules is confirmed. Moreover, point-estimates of the parameter $b_{\pi}$ are now much closer to each other. Also with this encompassing specification, the additional regressor $z_{t}$ seems to be quite relevant in fitting the path of the federal funds rate; the point estimates present in this Table are statistically in line with those seen in Table 3. As far as our key-parameters $\rho$ and $\rho_{\varepsilon}$ are concerned, both are statistically significant. The point-estimate of the coefficient $\rho$ is about 0.6 in all the three backward looking nested models considered here. Notably, this is lower of a magnitude of 0.2 with respect to what it is conventionally found. This seems to be due to the impact exerted by the explicitly modeled serial correlation process. In fact, the corresponding point estimate turns out to be quite robust to the introduction of omitted variables. Interestingly, the same does not hold for that of the $\mathrm{AR}(1)$ process, which falls from a value of about 0.58 to values lower than 0.4. Of course, this does not imply that the relative importance of the SC process lowers with respect to the one of the PA mechanisms. However, it seems to bring evidence in favor of a role of the lagged dependent variable per se in estimated Taylor rules, as underlined by ENS (2002).

When moving to the forward looking nested model (Table 6), we find confirmation of some already commented results. In particular, the estimated coefficients of the 1-year ahead inflation rate are lower than those in the backward looking counterpart; by contrast, those of the additional regressors are higher, so confirming their role as leading indicator of future inflation. The significance of both $\rho$ and $\rho_{\varepsilon}$ is confirmed, while the point estimates are higher for $\rho$ (and more in line with the literature, e.g. Clarida, Galí, and Gertler, 2000) and lower for $\rho_{\varepsilon}$ if compared to those of the backward looking case. Once more, it

estimates, we run regressions with survey data using NLS, as explained later in the text. 


\begin{tabular}{|c||ccc|}
\hline $\begin{array}{c}\text { Taylor rate } \\
\text { specification }\end{array}$ & $\begin{array}{c}\text { Standard } \\
\text { Taylor }\end{array}$ & $\begin{array}{c}\text { Asymmetric } \\
\text { preferences }\end{array}$ & $\begin{array}{c}\text { Credit } \\
\text { spread }\end{array}$ \\
\hline \hline$b_{\pi}$ & $1.397^{* *}$ & $1.433^{* *}$ & $1.359^{* *}$ \\
& $(0.371)$ & $(0.265)$ & $(0.195)$ \\
$b_{y}$ & $0.749^{* *}$ & $0.677^{* *}$ & $0.781^{* *}$ \\
$b_{z}$ & $(0.209)$ & $(0.132)$ & $(0.091)$ \\
& - & $-0.185^{*}$ & $-2.346^{* *}$ \\
& & $(0.072)$ & $(0.512)$ \\
& $0.609^{* *}$ & $0.637^{* *}$ & $0.618^{* *}$ \\
$\rho_{\varepsilon}$ & $(0.146)$ & $(0.096)$ & $(0.065)$ \\
$R^{2}$ & $0.578^{* *}$ & $0.379^{*}$ & 0.318 \\
$(0.202)$ & $(0.175)$ & $(0.161)$ \\
${ }^{*}=95 \% /^{* *}=99 \%$ & 0.970 & 0.980 \\
$\mathrm{i}_{t}=(1-\rho)\left(\mathrm{c}+\mathrm{b}_{\pi} \bar{\pi}_{t}+\mathrm{b}_{y} y_{t}+\mathrm{b}_{z} \mathrm{z}_{t}\right)+\rho_{t-1}+\varepsilon_{t}, \varepsilon_{t}=\rho_{\varepsilon} \varepsilon_{t-1}+\eta_{t}$ \\
$\mathrm{z}_{t}=y_{t}^{2}\left(\right.$ Asymmetric preferences); $\mathrm{z}_{t}=$ spread (Credit spread). \\
Estimator: NLS. Newey-West correction (3 lags) applied to the \\
standard errors (in brackets). c omitted for brevity. \\
\hline
\end{tabular}

Table 5: Nested PA-SC model: Backward Looking Taylor Rules

seems to be difficult to think about a Taylor rule whose persistence is exclusively determined by a SC process.

Robustness check: Approximating inflation expectations with survey-based data

GMM estimates are often seen as being fragile, and may heavily be instrumentdependent In fact, all the p-values presented in Tables 4 and 6 seem to suggest that the over-identifying restrictions imposed on our estimated models are statistically valid. However, as a check on the validity of our results, we estimate forward looking Taylor-type rules using a different strategy. Instead of instrumenting our one-year ahead inflation expectations, we exploit a series provided by the Survey of Professional Forecasters (SPF) conducted by the Federal Reserve Bank of Philadelphia. ${ }^{29}$ This provides us with an exogenous regressor, that can be employed in our econometric exercise without recurring to any instrument choice. Of course, we should naturally employ in such a regression also measures of expected output gap (in level and quadratic fashions) and

\footnotetext{
${ }^{29}$ For details regarding the survey data on 1-year ahead inflation expectations used in this paper, see the Data appendix.
} 


\begin{tabular}{|c|c|c|c|}
\hline $\begin{array}{l}\text { Taylor rate } \\
\text { specification }\end{array}$ & $\begin{array}{c}\text { Standard } \\
\text { Specification }\end{array}$ & $\begin{array}{l}\text { Asymmetric } \\
\text { preferences }\end{array}$ & $\begin{array}{l}\text { Credit } \\
\text { spread }\end{array}$ \\
\hline$b_{\pi}$ & $\begin{array}{c}1.379^{* *} \\
(0.521)\end{array}$ & $\begin{array}{c}1.171^{* *} \\
0.330)\end{array}$ & $\begin{array}{c}1.024^{* *} \\
(0.144)\end{array}$ \\
\hline$b_{y}$ & $\begin{array}{c}0.803^{* *} \\
(0.174)\end{array}$ & $\begin{array}{c}0.546^{* *} \\
(0.103)\end{array}$ & $\begin{array}{c}0.183^{*} \\
(0.073)\end{array}$ \\
\hline$b_{z}$ & - & $\begin{array}{l}-0.293^{* *} \\
(0.078)\end{array}$ & $\begin{array}{l}-4.465^{* *} \\
(0.265)\end{array}$ \\
\hline$\rho$ & $\begin{array}{c}0.846^{* *} \\
(0.037)\end{array}$ & $\begin{array}{c}0.826^{* *} \\
(0.024)\end{array}$ & $\begin{array}{c}0.794^{* *} \\
(0.020)\end{array}$ \\
\hline$\rho_{\varepsilon}$ & $\begin{array}{c}0.438^{* *} \\
(0.073)\end{array}$ & $\begin{array}{c}0.319^{* *} \\
(0.108)\end{array}$ & $\begin{array}{l}0.295^{* *} \\
(0.043)\end{array}$ \\
\hline $\bar{R}^{2}$ & 0.937 & 0.950 & 0.971 \\
\hline $\begin{array}{c}\text { Over. Restr. } \\
(J-\text { statistic }, p-\text { value })\end{array}$ & $\begin{array}{c}0.917 \\
\left(\chi^{2}(12)\right)\end{array}$ & $\begin{array}{c}0.962 \\
\left(\chi^{2}(15)\right)\end{array}$ & $\begin{array}{c}0.943 \\
\left(\chi^{2}(15)\right)\end{array}$ \\
\hline \multicolumn{4}{|c|}{$\begin{array}{l}{ }^{*}=95 \% /^{* *}=99 \% \text { rejection of the null hyp. Estimated model: } \\
\mathrm{i}_{t}=(1-\rho)\left(\mathrm{c}+\mathrm{b}_{\pi} E_{t-1} \bar{\pi}_{t+4}+\mathrm{b}_{y} \mathrm{E}_{t-1} y_{t}+\mathrm{b}_{z} \mathrm{E}_{t-1} \mathrm{z}_{t}\right)+\rho \mathrm{i}_{t-1}+\varepsilon_{t}, \varepsilon_{t}=\rho_{\varepsilon} \varepsilon_{t-1}+\eta_{t} \\
\mathrm{z}_{t}=y_{t}^{2} \text { (Asymmetric preferences); } \mathrm{z}_{t}=\text { spread (Credit spread). } \\
\text { Estimates performed via GMM. Instruments: } \\
{\left[\mathrm{c} \bar{\pi}_{t-2} . . \bar{\pi}_{t-5} y_{t-2} . . y_{t-5} \Delta i_{t-2} . . \Delta i_{t-5} \Delta \bar{\pi}_{t-2}^{P P I} . . \Delta \bar{\pi}_{t-5}^{P P I} \Delta z_{t-2} . . \Delta z_{t-5}\right],} \\
\bar{\pi}_{t}^{P P I} \text { four quarter inflation from the Producer Price Index (Finished Goods). } \\
\text { Newey-West correction (Bartlett kernel, } 3 \text { lags) applied to the stand. errors } \\
\text { (reported in brackets). c omitted for brevity. }\end{array}$} \\
\hline
\end{tabular}

Table 6: Nested PA-SC model: Forward Looking Taylor Rules

expected credit spread; this approach would be in line with forward looking Taylor rules such as those estimated via GMM in this work. Unfortunately, this is much less feasible. In fact, there are not official real-time estimates of potential GDP, which could allow us to construct an expected output gap series. Moreover, the Federal Reserve Bank of Philadelphia does not provide any measure of expected yield from risky financial investments, such as the Moody's BAA corporate index yield we employed to construct our measure of ex-post credit spread. Then, somewhat arbitrarily, we change the timing-assumption on the CB's expectations formation, and we estimate Taylor rules whose forwardlookingness is related just to the inflation rate. Practically, we consider the following two equations:

$$
\begin{aligned}
\Delta i_{t}= & \gamma_{2}\left(b_{\pi} \Delta E_{t} \pi_{t+4}^{S P F}+b_{y} \Delta y_{t}+b_{z} \Delta z_{t}\right) \\
& +\gamma_{3}\left(c+b_{\pi} E_{t-1} \pi_{t+3}^{S P F}+b_{y} y_{t-1}+b_{z} z_{t-1}-i_{t-1}\right)+\eta_{t}
\end{aligned}
$$

to test for the PA versus SC dynamic mechanisms, and 


\begin{tabular}{|c|c|c|c|}
\hline $\begin{array}{c}\text { Taylor rate } \\
\text { specification }\end{array}$ & $\begin{array}{c}\text { Standard } \\
\text { Specification }\end{array}$ & $\begin{array}{l}\text { Asymmetric } \\
\text { preferences }\end{array}$ & $\begin{array}{l}\text { Credit } \\
\text { spread }\end{array}$ \\
\hline ב & $2.157^{* *}$ & $101.983^{* *}$ & $1.963^{* *}$ \\
\hline$b_{u}$ & $0.867^{* *}$ & $\begin{array}{l}(0.239) \\
0.750^{* *}\end{array}$ & $\begin{array}{l}(0.228) \\
0.841^{* *}\end{array}$ \\
\hline & $(0.141)$ & $(0.128)$ & $(0.098)$ \\
\hline$b_{z}$ & - & $\begin{array}{l}-0.139^{*} \\
(0.059)\end{array}$ & $\begin{array}{c}-1.860^{* *} \\
(0.445)\end{array}$ \\
\hline$\gamma_{2}$ & $0.375^{* *}$ & $0.344^{* *}$ & $0.375^{* *}$ \\
\hline$\gamma_{3}$ & $0.274^{* *}$ & $0.281^{* *}$ & $0.279^{* *}$ \\
\hline $\bar{R}^{2}$ & 0.970 & 0.973 & 0.981 \\
\hline$H_{0}: \gamma_{2}=1$ & $0.000^{* *}$ & $0.000^{* *}$ & $0.000^{* *}$ \\
\hline $\begin{array}{c}(F-\text { tost }, p-\text { value }) \\
H_{0}: \gamma_{2}=\gamma_{3} \\
(F-\text { test }, p-\text { value })\end{array}$ & 0.098 & 0.378 & 0.068 \\
\hline \multicolumn{4}{|c|}{$\begin{array}{l}{ }^{*}=95 \% /^{* *}=99 \% \text { rejection of the null hyp. Estimated model: } \\
\Delta \mathrm{i}_{t}=\gamma_{2}\left(\mathrm{~b}_{\pi} \Delta \mathrm{E}_{t} \pi_{t+4}^{S P F}+\mathrm{b}_{y} \Delta \mathrm{y}_{t}+\mathrm{b}_{z} \Delta \mathrm{z}_{t}\right)+\gamma_{3}\left(\mathrm{c}+\mathrm{b}_{\pi} \mathrm{E}_{t-1} \pi_{t-3}^{S P F}+\mathrm{b}_{y} \mathrm{y}_{t-1}+\mathrm{b}_{z} \mathrm{z}_{t-1}-\mathrm{i}_{t-1}\right)+\eta_{t} . \\
\mathrm{z}_{t}=y_{t}^{2} \text { (Asymm. pref.); } \mathrm{z}_{t}==\text { spread (Credit spread). Estimator: NLS. } \\
\pi_{t+4}^{S P}=1 \text {-year ahead Expected Inflation from Survey of Professional Forecasters. } \\
\text { Newey-West correction (3 lags) applied to the st. errors (in brackets). } \\
\text { c omitted for brevity. } \bar{R}^{2} \text { refers to the level of the federal funds rate. }\end{array}$} \\
\hline
\end{tabular}

Table 7: Test for PA versus SC: Taylor Rules, SPF Expected Inflation

$$
i_{t}=(1-\rho)\left(c+b_{\pi} E_{t} \pi_{t+4}^{S P F}+b_{y} y_{t}+b_{z} z_{t}\right)+\rho i_{t-1}+\varepsilon_{t}, \varepsilon_{t}=\rho_{\varepsilon} \varepsilon_{t-1}+\eta_{t}
$$

to gain some insights on the possible coexistence between PA and SC. Notice that, given the timing assumption underling these two models, and given the exogeneity of the SPF inflation forecasts, we can consistently estimate equations (15) and (16) via NLS. ${ }^{30}$

A comparison of the figures in Tables 4 with those in Tables 7 triggers some thoughts. First of all, all these coefficients have the expected signs. Also with survey data the Taylor principle turns out to be respected, even if the estimated coefficients are remarkably larger with respect to the GMM ones. This does not

\footnotetext{
${ }^{30} \mathrm{~A}$ check on the robustness of these results was performed by implementing IV estimations (instrument for the SPF inflation expectations: its lag), and confirmed us that those figures are pretty robust in this sense. IV estimates are available upon request.
} 


\begin{tabular}{|c||ccc|}
\hline $\begin{array}{c}\text { Taylor rate } \\
\text { specification }\end{array}$ & $\begin{array}{c}\text { Standard } \\
\text { Specification }\end{array}$ & $\begin{array}{c}\text { Asymmetric } \\
\text { preferences }\end{array}$ & $\begin{array}{c}\text { Credit } \\
\text { spread }\end{array}$ \\
\hline \hline$b_{\pi}$ & $2.110^{* *}$ & $1.976^{* *}$ & $1.934^{* *}$ \\
& $(0.241)$ & $0.215)$ & $(0.173)$ \\
$b_{y}$ & $0.827^{* *}$ & $0.729^{* *}$ & $0.812^{* *}$ \\
$b_{z}$ & $(0.118)$ & $-0.107)$ & $(0.082)$ \\
& - & $(0.060)$ & $-1.654^{* *}$ \\
$\rho$ & $0.652^{* *}$ & $0.673^{* *}$ & $0.653^{* *}$ \\
$\rho_{\varepsilon}$ & $(0.059)$ & $0.050)$ & $(0.042)$ \\
$R^{2}$ & 0.296 & 0.177 & 0.141 \\
$(0.154)$ & 0.973 & 0.976 & $0.161)$ \\
${ }^{*}=95 \% /^{* *}=99 \%$ rejection of the null hyp. & Estimated model: \\
$\mathrm{i}_{t}=\left(\mathrm{c}+\mathrm{b}_{\pi} E_{t} \pi_{t+4}^{S P}+\mathrm{b}_{y} y_{t}+\mathrm{b}_{z} \mathrm{z}_{t}\right)+\rho \mathrm{i}_{t-1}+\varepsilon_{t}, \varepsilon_{t}=\rho_{\varepsilon} \varepsilon_{t-1}+\eta_{t}$ \\
$\mathrm{z}_{t}=y_{t}^{2}$ (Asymmetric preferences); $\mathrm{z}_{t}=$ spread $($ Credit spread). \\
Estimator: NLS. Newey-West correction (3 lags) applied to \\
the st. errors (in brackets). c omitted for brevity. \\
\hline
\end{tabular}

Table 8: Nested PA-SC Model: Taylor Rules, SPF Expected Inflation

seem to hold for the output gap figures we estimated; notably, the output gap turns out to be statistically significant in all the estimated rules. The same holds for the additional variables, which show lower point estimates with respect to those obtained via GMM. The reason of such differences may be attributed to the nature of the SPF inflation expectations, that are not fully rational from a statistical viewpoint (Roberts, 1998).

As already seen in all the previously commented cases, the test on the null (11) suggests a rejection of the hypothesis of SC as the unique engine of the federal funds rate dynamics. By contrast, the PA testable restriction is not rejected, even if the $\mathrm{p}$-values are pretty low.

Moving to Tables 6 and 8, we observe that the above written considerations regarding the estimated coefficients still hold. In fact, the remarkable result obtained with SPF inflation forecasts is that the SC coefficient is never statistically significant at the $95 \%$ confidence interval, while the PA one is always significant at the $99 \%$ level. Of course, if this does not necessarily imply that $\mathrm{SC}$ is not important for shaping an empirically relevant Taylor rules, a fortiori it should not cast doubts on the relevance of the smoothing argument in the estimated Taylor rules. 


\section{A note on real time data analyses}

In this paper we use revised data; in fact, these data were not available to the Federal Open Market Committee Members when they took their decisions. What if we used real time data? Lansing (2002) simulates a model in which a $\mathrm{CB}$ sets the policy rate without any smoothing, and on the basis of real time estimates of the potential output. In Lansing's study, the measurement error regarding the potential output estimates is serially correlated, because monetary authorities need time to learn about the new potential output process after a shock has occurred. Lansing discusses how an econometrician who used final, revised data would obtain upward biased estimates of the parameter $\rho$ relative to the true value, because the lagged interest rate captures the omitted, serially correlated, measurement error. Indeed, Lansing (2002)'s conclusions support Rudebusch (2002a)'s claim on the massive relative importance of SC versus PA. Mehra (2001) also supports Rudebusch (2002a)'s findings. In particular, he works with real time data, and estimates the potential output as a simple log-linear trend of the GDP. His estimates of the partial adjustment coefficient are indeed low, and sometimes even not significant.

So, are our results misleading? In fact, the impact of real time data on the estimated value of the smoothing parameter is still disputed. Perez (2001) and Orphanides (2001) estimate Taylor rules with real time data, and still obtain high estimated figures regarding the interest rate smoothing coefficients. ${ }^{31}$ Moreover, in estimating the nested model (3) we explicitly allow for a serially correlated error term. This choice, not frequently taken in this literature, should enable us to catch the omitted variable effect highlighted by Lansing (2002).

Therefore, from a quantitative point of view, the use of revised data does not necessarily lead to dramatic consequences for our results. ${ }^{32}$ Here, we would like to stress the fact that the autoregressive coefficient $\rho$ could indeed have a lower magnitude with respect to the standard assessment of 0.8. However, this does not necessarily imply that the Fed has not smoothed the federal funds rate. Indeed, it could be the case that the sluggishness discussed so far in the literature is not so high, but it is still present.

\footnotetext{
${ }^{31}$ Notice that Lansing (2002) and Mehra (2001) focus on the interest rate smoothing value in the policy rule estimation. Instead, Perez (2001)'s paper regards the (non) accommodativeness of the monetary policy in the '70s, while Orphanides (2001) concentrates on the different policy recommendations arising when using revised vs. real time data.

${ }^{32} \mathrm{~A}$ similar point about the smoothing parameter is made by Brüggemann and Thornton (2002).
} 


\section{Conclusions}

In this paper we have focussed our attention on the interest rate smoothing argument in Taylor-type schemes. In a recent contribution, Rudebusch (2002a) intriguingly challenges the conventional wisdom, and states that the interest rate smoothing behavior at quarterly frequencies is just an illusion. As indirect proof, he claims that if this was not the case, then rational agents should be capable of predicting future movements of the policy rate. Indeed, this is not what happens in reality.

By applying English, Nelson, and Sack (2002)'s modeling strategy to US data, in this paper we assessed the significance of both the interest rate smoothing argument and the serially correlated policy deviations from the Taylor rate prescriptions. In particular, we estimated 9 models in first differences to test for the 'pure' partial adjustment hypothesis versus the one of 'pure' serial correlation. Notably, in all the 9 cases considered in our exercise, the null of pure serial correlation process was rejected. By contrast, the PA mechanism was supported by 7 cases out of 9 ; however, for some of these cases the p-values suggest cautiousness in the interpretation of these results. Then, we estimated 9 encompassing models, i.e. 9 models admitting both interest rate smoothing and serially correlated policy shocks. While the significance of the interest rate smoothing coefficient turns out to be overwhelming, that of the AR(1) shocks is not supported in 4 cases out of 9 .

Indeed, credit crunches or financial crises represent shocks that may very well suggest serially correlated deviations with respect to the policy recommended by the Taylor rate; in this sense, we are sympathetic with Rudebusch (2002a)'s argument. Nevertheless, our estimates indicate that the lagged interest rate does play a key-role in a Taylor-type model. By contrast, the presence of a serially correlated policy shock, although often statistically relevant, does not seem to be sufficient in explaining the observed interest rate gradualism. Therefore, our results do not necessarily contradict Rudebusch (2002a)'s claim on the significance of a serially correlated error term in estimated Taylor rules, but strongly support English, Nelson, and Sack (2002)'s conclusion on the key-role played by the lagged depended variable in this type of policy functions. 
Interestingly, the simple average computed on the 9 different estimated interest rate smoothing coefficients is about 0.7 , a value lower than the 'standard' 0.8. This may suggest that monetary authorities act gradually, but probably respond faster than claimed in the literature to shocks affecting the Taylor rate. Hence, Rudebusch (2002a)'s conjecture on the 'exaggerated' magnitude usually attributed to the interest rate smoothing component is also supported by our estimates.

Finally, our empirical findings seem to call for further research on nonstandard explanatory variables to be included into Taylor type regressions. Asymmetric policy preferences (Surico, 2002) and financial indicators (GerlachKristen, 2002) are surely worthy of further investigation from both a positive and a normative side, also in the light of some recent contributions on the relationship between asymmetric preferences and ex-ante average inflation bias (Cukierman and Muscatelli, 2002, Cukierman and Gerlach, 2003, and Surico, 2003), and on the importance of financial markets evolution for monetary policy decisions (Cecchetti, Genberg, and Wadhwani, 2002). 


\section{Technical appendix}

In this Technical appendix we describe how we built up our Figure 1.

Our economy is basically identified by the following 4 equations: (3), (4), (6), and (7). This is a recursive economy, whose law of motion can be easily defined. To do it, the first step to undertake is to rewrite equations (6) and (7):

$$
\begin{aligned}
\pi_{t+1}= & \mu_{\pi} E_{t}\left(\frac{\pi_{t+1}+\pi_{t+2}+\pi_{t+3}+\pi_{t+4}}{4}\right) \\
& +\left(1-\mu_{\pi}\right)\left(\alpha_{\pi 1} \pi_{t}+\alpha_{\pi 2} \pi_{t-1}+\alpha_{\pi 3} \pi_{t-2}+\alpha_{\pi 4} \pi_{t-3}\right)+\alpha_{y} y_{t}+\varepsilon_{t+1}^{\pi} \\
y_{t+1}= & \mu_{y} E_{t} y_{t+2}+\left(1-\mu_{y}\right)\left(\beta_{y 1} y_{t}+\beta_{y 2} y_{t-1}\right) \\
& -\beta_{r} \mu_{r}\left[i_{t}-E_{t}\left(\frac{\pi_{t+1}+\pi_{t+2}+\pi_{t+3}+\pi_{t+4}}{4}\right)\right] \\
& -\frac{\beta_{r}\left(1-\mu_{r}\right)}{4}\left(i_{t}+i_{t-1}+i_{t-2}+i_{t-3}-\pi_{t}-\pi_{t-1}-\pi_{t-2}-\pi_{t-3}\right)+\varepsilon_{t+1}^{y}
\end{aligned}
$$

Our aim is to compute the expectations terms $E_{t} \pi_{t+4}$ and $E_{t} y_{t+2}$. Noticing that $\pi_{t+1}=E_{t} \pi_{t+1}+\varepsilon_{t+1}^{\pi}$ and $y_{t+1}=E_{t} y_{t+1}+\varepsilon_{t+1}^{y}$ (where $\varepsilon_{t+1}^{\pi}$ and $\varepsilon_{t+1}^{y}$ are white noise processes), it is then possible to manipulate (17) and (18) as follows:

$$
\begin{aligned}
\frac{\mu_{\pi} E_{t} \pi_{t+4}}{4}= & \left(1-\frac{\mu_{\pi}}{4}\right) E_{t} \pi_{t+1}-\frac{\mu_{\pi}}{4} E_{t} \pi_{t+2}-\frac{\mu_{\pi}}{4} E_{t} \pi_{t+3} \\
-\left(1-\mu_{\pi}\right)\left(\alpha_{\pi 1} \pi_{t}+\alpha_{\pi 2} \pi_{t-1}+\alpha_{\pi 3} \pi_{t-2}+\alpha_{\pi 4} \pi_{t-3}\right)-\alpha_{y} y_{t} & \\
\mu_{y} E_{t} y_{t+2}+\beta_{r} \mu_{r} E_{t} \pi_{t+4}= & E_{t} y_{t+1}-\left(1-\mu_{y}\right)\left(\beta_{y 1} y_{t}+\beta_{y 2} y_{t-1}\right) \\
& +\beta_{r} \mu_{r}\left[i_{t}-E_{t}\left(\frac{\pi_{t+1}+\pi_{t+2}+\pi_{t+3}}{4}\right)\right] \\
& +\frac{\beta_{r}\left(1-\mu_{r}\right)}{4} \sum_{i=0}^{3}\left(i_{t-i}-\pi_{t-i}\right)
\end{aligned}
$$

The Central Banker policy rule is described in our experiment by a simple Taylor rule allowing for Partial Adjustment and Serially Correlated deviations:

$$
i_{t}=(1-\rho)\left(b_{\pi} \pi_{t}+b_{y} y_{t}\right)+\rho_{t-1}+\varepsilon_{t}
$$




$$
\varepsilon_{t}=\rho_{\varepsilon} \varepsilon_{t-1}+\eta_{t}
$$

It should be noticed that this formulation of the economic environment implies the presence of $n 1=10$ predetermined variables ${ }^{33}$ which can be stacked into the vector

$$
x_{1 t}=\left[\begin{array}{llllllllll}
\pi_{t} & \pi_{t-1} & \pi_{t-2} & \pi_{t-3} & y_{t} & y_{t-1} & i_{t-1} & i_{t-2} & i_{t-3} & \varepsilon_{t}
\end{array}\right]^{\prime}
$$

Moreover, there are $n 2=4$ jump variables, namely

$$
x_{2 t}=\left[\begin{array}{llll}
E_{t} \pi_{t+3} & E_{t} \pi_{t+2} & E_{t} \pi_{t+1} & E_{t} y_{t+1}
\end{array}\right]^{\prime}
$$

Since we are solving a stochastic problem, we also define the $n 1 x 1$ vector of shocks to the predetermined variables as:

$$
v_{1 t+1}=\left[\begin{array}{llllll}
\varepsilon_{t+1}^{\pi} & 0_{1 x 3} & \varepsilon_{t+1}^{y} & 0_{1 x 4} & \eta_{t+1} & 0_{1 x 4}
\end{array}\right]^{\prime}
$$

Then, the state-space representation of the problem is the following:

$$
A_{0}\left[\begin{array}{c}
x_{1 t+1} \\
E_{t} x_{2 t+1}
\end{array}\right]=A_{1}\left[\begin{array}{l}
x_{1 t} \\
x_{2 t}
\end{array}\right]+B_{1} i_{t}+v_{t+1}
$$

where

$$
v_{t+1}=\left[\begin{array}{l}
v_{1 t+1} \\
0_{n 2 x 1}
\end{array}\right]
$$

and the matrices $A_{0}, A_{1}$, and $B_{1}$ read as follows:

\footnotetext{
${ }^{33}$ The timing of our economic game is the following: 1) at the beginning of each period private agents form their expectations; 2) then, the interest rate level is optimally fixed by the Central Bank, and 3) the demand and supply shocks strike the economy.
} 


$$
\begin{aligned}
& A_{0}=\left[\begin{array}{cccccccccccccc}
1 & 0 & 0 & 0 & 0 & 0 & 0 & 0 & 0 & 0 & 0 & 0 & 0 & 0 \\
0 & 1 & 0 & 0 & 0 & 0 & 0 & 0 & 0 & 0 & 0 & 0 & 0 & 0 \\
0 & 0 & 1 & 0 & 0 & 0 & 0 & 0 & 0 & 0 & 0 & 0 & 0 & 0 \\
0 & 0 & 0 & 1 & 0 & 0 & 0 & 0 & 0 & 0 & 0 & 0 & 0 & 0 \\
0 & 0 & 0 & 0 & 1 & 0 & 0 & 0 & 0 & 0 & 0 & 0 & 0 & 0 \\
0 & 0 & 0 & 0 & 0 & 1 & 0 & 0 & 0 & 0 & 0 & 0 & 0 & 0 \\
0 & 0 & 0 & 0 & 0 & 0 & 1 & 0 & 0 & 0 & 0 & 0 & 0 & 0 \\
0 & 0 & 0 & 0 & 0 & 0 & 0 & 1 & 0 & 0 & 0 & 0 & 0 & 0 \\
0 & 0 & 0 & 0 & 0 & 0 & 0 & 0 & 1 & 0 & 0 & 0 & 0 & 0 \\
0 & 0 & 0 & 0 & 0 & 0 & 0 & 0 & 0 & 1 & 0 & 0 & 0 & 0 \\
0 & 0 & 0 & 0 & 0 & 0 & 0 & 0 & 0 & 0 & \frac{\gamma_{\pi}}{4} & 0 & 0 & 0 \\
0 & 0 & 0 & 0 & 0 & 0 & 0 & 0 & 0 & 0 & 0 & 1 & 0 & 0 \\
0 & 0 & 0 & 0 & 0 & 0 & 0 & 0 & 0 & 0 & 0 & 0 & 1 & 0 \\
0 & 0 & 0 & 0 & 0 & 0 & 0 & 0 & 0 & 0 & \frac{\beta_{r} \gamma_{r}}{4} & 0 & 0 & \gamma_{y}
\end{array}\right] \\
& A_{1}=\left[\begin{array}{cccccccccccccc}
0 & 0 & 0 & 0 & 0 & 0 & 0 & 0 & 0 & 0 & 0 & 0 & 1 & 0 \\
1 & 0 & 0 & 0 & 0 & 0 & 0 & 0 & 0 & 0 & 0 & 0 & 0 & 0 \\
0 & 1 & 0 & 0 & 0 & 0 & 0 & 0 & 0 & 0 & 0 & 0 & 0 & 0 \\
0 & 0 & 1 & 0 & 0 & 0 & 0 & 0 & 0 & 0 & 0 & 0 & 0 & 0 \\
0 & 0 & 0 & 0 & 0 & 0 & 0 & 0 & 0 & 0 & 0 & 0 & 0 & 1 \\
0 & 0 & 0 & 0 & 1 & 0 & 0 & 0 & 0 & 0 & 0 & 0 & 0 & 0 \\
0 & 0 & 0 & 0 & 0 & 0 & 0 & 0 & 0 & 0 & 0 & 0 & 0 & 0 \\
0 & 0 & 0 & 0 & 0 & 0 & 1 & 0 & 0 & 0 & 0 & 0 & 0 & 0 \\
0 & 0 & 0 & 0 & 0 & 0 & 0 & 1 & 0 & 0 & 0 & 0 & 0 & 0 \\
0 & 0 & 0 & 0 & 0 & 0 & 0 & 0 & 0 & \rho & 0 & 0 & 0 & 0 \\
\widetilde{\alpha}_{\pi 1} & \widetilde{\alpha}_{\pi 2} & \widetilde{\alpha}_{\pi 3} & \widetilde{\alpha}_{\pi 4} & -\alpha_{y} & 0 & 0 & 0 & 0 & 0 & -\frac{\gamma_{\pi}}{4} & -\frac{\gamma_{\pi}}{4} & \left(1-\frac{\gamma_{\pi}}{4}\right) & 0 \\
0 & 0 & 0 & 0 & 0 & 0 & 0 & 0 & 0 & 0 & 1 & 0 & 0 & 0 \\
0 & 0 & 0 & 0 & 0 & 0 & 0 & 0 & 0 & 0 & 0 & 1 & 0 & 0 \\
\widehat{\beta}_{r} & \widehat{\beta}_{r} & \widehat{\beta}_{r} & \widehat{\beta}_{r} & \widetilde{\beta}_{y 1} & \widetilde{\beta}_{y 2} & -\widehat{\beta}_{r} & -\widehat{\beta}_{r} & -\widehat{\beta}_{r} & 0 & -\frac{\beta_{r} \gamma_{r}}{4} & -\frac{\beta_{r} \gamma_{r}}{4} & -\frac{\beta_{r} \gamma_{r}}{4} & 1
\end{array}\right] \\
& B_{1}=\left[\begin{array}{llll}
0_{1 x 6} & 1 & 0_{1 x 6} & \beta_{r}\left(\gamma_{r}+\frac{\left(1-\gamma_{r}\right)}{4}\right)
\end{array}\right]^{\prime}
\end{aligned}
$$

with $\widetilde{\alpha}_{\pi j}=-\left(1-\gamma_{\pi}\right) \alpha_{\pi j}, \widehat{\beta}_{r}=-\frac{\beta_{r}\left(1-\gamma_{r}\right)}{4}, \widetilde{\beta}_{y j}=-\left(1-\gamma_{y}\right) \beta_{y j}$.

To get the standard state-space representation, we just have to pre-multiply (26) by $A_{0}^{-1}$, so obtaining

$$
\left[\begin{array}{c}
x_{1 t+1} \\
E_{t} x_{2 t+1}
\end{array}\right]=A\left[\begin{array}{l}
x_{1 t} \\
x_{2 t}
\end{array}\right]+B i_{t}+v_{t+1}
$$

where $A=A_{0}^{-1} A_{1}$ and $B=A_{0}^{-1} B_{1}{ }^{34}$

\footnotetext{
${ }^{34}$ Notice that $A_{0}^{-1} v_{t+1}=v_{t+1}$, since $A_{0}$ is block diagonal with an identity matrix as its upper left block and the lower block of $v_{t+1}$ is equal to zero.
} 
In our exercise, the CB sticks to the simple rule (21). That rule can be re-written in compact form as

$$
i_{t}=-F x_{t}
$$

where $F$ is the following $1 x(n 1+n 2)$ row vector:

$$
F=\left[\begin{array}{llllllllll}
\tilde{b_{\pi}} & \widetilde{b_{\pi}} & \widetilde{b_{\pi}} & \widetilde{b_{\pi}} & (1-\rho) b_{y} & 0 & \rho & 0_{1 x 2} & 1 & 0_{1 x 4}
\end{array}\right]
$$

where $\tilde{b}_{\pi}=\frac{(1-\rho) b_{\pi}}{4}$.

Then, (27) and (28) imply this law of motion:

$$
\left[\begin{array}{c}
x_{1 t+1} \\
E_{t} x_{2 t+1}
\end{array}\right]=(A-B F)\left[\begin{array}{l}
x_{1 t} \\
x_{2 t}
\end{array}\right]+v_{t+1}
$$

Provided that the $F$ vector leads the system to a unique equilibrium, Söderlind (1999) shows how to compute the matrices $M(n 1 x n 1)$ and $C(n 2 x n 2)$ such that $^{35}$

$$
x_{1 t+1}=M x_{1 t}+v_{1 t+1}
$$

$$
x_{2 t}=C x_{1 t}
$$

Therefore, by jointly considering (28)-(32), we can simulate different policy rates, in particular focussing on different pairs $\left(\rho, \rho_{\varepsilon}\right)$. The values of the parameters used to build up Figure 1 are indicated below that Figure. ${ }^{36}$

\footnotetext{
${ }^{35}$ The computation of these matrices exploits the generalized Schur decomposition. Paul Söderlind's codes provide the user with the latter, as well as with the matrices $M$ and $C$. His codes are available at this URL: http://www.hhs.se/personal/psoderlind/Software/Software.htm.

${ }^{36}$ Notice that the shocks $\eta_{t+1}$, as well as the initial value $\varepsilon_{0}$, are defined with a two-step procedure, by first estimating the Taylor rule (21), and then estimating an AR(1) process for the estimated residuals obtained in Step 1.
} 


\section{Data appendix}

The short term rate used in our analysis is the federal funds rate. The quarterly inflation rate has been computed by using the GDP chain-weighted price index $P_{t}$. Our measure of output $Q_{t}$ is the chain weighted real GDP. The potential output $Q_{t}^{*}$ series is the one estimated by the Congressional Budget Office. The variables used in our study have been constructed as follows: $\pi_{t}$ is the fourquarter inflation rate computed via the price index $\left(P_{t}\right)$, i.e. $\pi_{t} \equiv 4\left(p_{t}-\right.$ $p_{t-1}$ ), where $p_{t}=100 \ln P_{t} . \quad y_{t}$ is the output gap, which has been defined as $q_{t}-q_{t}^{*}$, where $q_{t} \equiv 100 \ln Q_{t}$, while $q_{t}^{*} \equiv 100 \ln Q_{t}^{*}$. The credit spread has been built as the difference between the Moody's BAA corporate index yield and the 10-year US treasury note yield. Finally, the upper-barred variables indicate simple averages taken over the contemporaneous observation and the previous three lags of the variable in consideration. All these series, together with the Producer Price Index (Finished Goods) exploited as an instrument in our GMM estimations, were downloaded from the Federal Reserve Bank of St. Louis web site, i.e. http://research.stlouisfed.org/fred2/. The series on one-year ahead inflation expectations used for estimating the models (15) and (16) were taken from the Federal Reserve Bank of Philadelphia web site, i.e. http://www.phil.frb.org/files/spf/cpie1.txt. In our exercise, we used oneyear ahead inflation forecast (average). For reasons of time-series continuity, we considered the measure of inflation computed on the basis of the consumer price index. All the variables used either as depended variable or as regressors in our econometric exercises are depicted in Figure 2. 

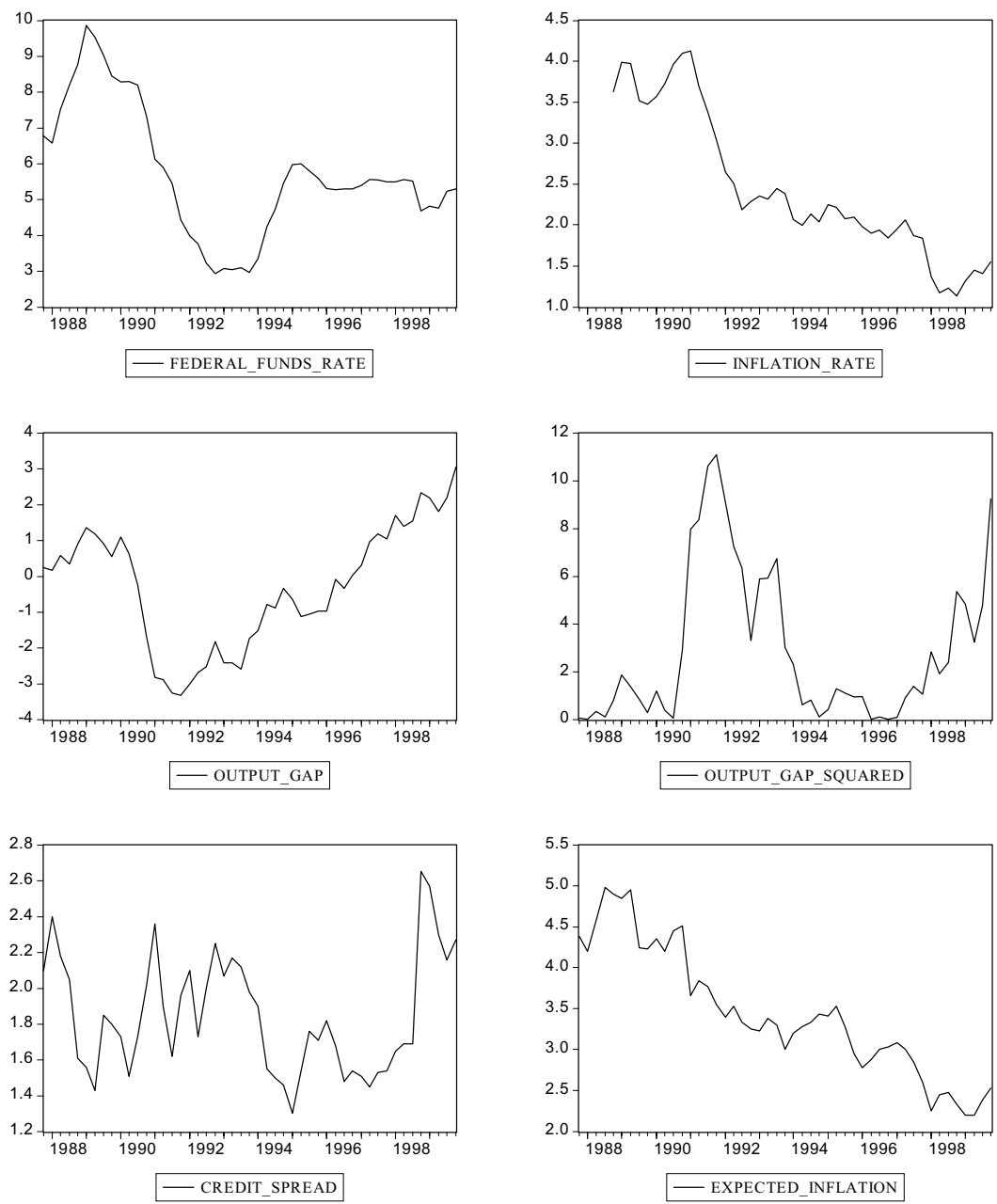

Figure 2: US series 


\section{References}

Amato, J., and T. Laubach, 1999, The Value of Interest Rate Smoothing: How the Private Sector Helps the Federal Reserve, Economic Review, Federal Reserve Bank of Kansas City, 47-64.

Bernanke, B., and A. Blinder, 1988, Credit, Money, and Aggregate Demand, American Economic Review, May, 78(2), 435-439.

Bernanke, B., and M. Gertler, 1995, Inside the Black Box: The Credit Channel of Monetary Transmission, Journal of Economic Perspectives, 9(4), 27-48, Fall.

Bernanke, B., M. Gertler, and S. Gilchrist, 1996, The Financial Accelerator and the Flight to Quality, Review of Economics and Statistics, 78(1), 1-15.

Bernanke, B. S., and M. Gertler, 2001, Should Central Banks Respond to Movements in Asset Prices?, American Economic Review Papers and Proceedings, 91(2), May, 253-257.

Bertocchi, G., and M. Spagat, 1993, Learning, Experimentation, and Monetary Policy, Journal of Monetary Economics, 32 (1), 169-183.

Blinder, A.S., 1997, What Central Bankers Could Learn from Academics-and Vice Versa, Distinguished Lecture on Economics in Government, Journal of Economic Perspectives, 11(2), 3-19.

Blinder, A.S., 1998, Central banking in theory and practice, The MIT Press, Cambridge, Massachusetts.

Brainard, W., 1967, Uncertainty and the Effectiveness of Policy, American Economic Review Papers and Proceedings, 57, 211-425.

Brüggemann, I., and D.L. Thornton, 2002, Interest Rate Smoothing and the Specification of The Taylor Rule, mimeo.

Caplin, A., and J. Leahy, 1996, Monetary Policy as a Process of Search, American Economic Review, 86 (4), 689-702.

Castelnuovo, E., 2003, Squeezing the Interest Rate Smoothing Weight with a Hybrid New-Keynesian Model, FEEM Working Paper, No. 06-2003.

Castelnuovo, E., and P. Surico, 2003, Model Uncertainty, Optimal Monetary Policy, and the Preferences of the Fed, Scottish Journal of Political Economy, forthcoming.

Cecchetti, S.G., 2000, Making Monetary Policy: Objectives and Rules, Oxford Review of Economic Policy, 16(4), 43-59.

Cecchetti, S.G., A. Flores Lagunes and Stefan Krause, 2001. Has monetary policy become more efficient? A cross country analysis. Mimeo, Ohio State University. 
Cecchetti, S.G., H. Genberg, and S. Wadhwani, 2002, Asset Prices in a Flexible Inflation Targeting Framework, NBER Working Paper No. 8970.

Christiano, L., M. Eichenbaum, and C.Evans, 1998, Monetary Policy Shocks: What Have We Learnt and to What End, NBER Working Paper No. 6400.

Clarida, R, J. Gali, and M. Gertler, 1998, Monetary Policy Rules in Practice: Some International Evidence, European Economic Review, 42, 1033-1067.

Clarida, R, J. Gali, and M. Gertler, 1999, The Science of Monetary Policy: A New Keynesian Perspective, Journal of Economic Literature, XXXVII, December, 1661-1707.

Clarida, R, J. Gali, and M. Gertler, 2000, Monetary Policy Rules and Macroeconomic Stability: Evidence and Some Theory, Quarterly Journal of Economics, 115, 147-180.

Cukierman, A., and V. A. Muscatelli, 2002, Do Central Banks have Precautionary Demands for Expansions and for Price Stability? Theory and Evidence, mimeo.

Cukierman, A., and S. Gerlach, 2003, The inflation bias revisited: Theory and some international evidence, CEPR Discussion Paper Series, No. 3761.

Doménech, R., M. Ledo, and D. Taguas, 2002, Some new results on interest rate rules in EMU and in the US, Journal of Economics and Business, 54, 431-446.

English, W.B, W.R. Nelson, and B. Sack, 2002, Interpreting the Significance of the Lagged Interest Rate in Estimated Monetary Policy Rules, Federal Reserve Bank of Washington, Finance and Economics Discussion Series Working Paper No. 2002-24.

Estrella, A. and F.S. Mishkin, 1999, Rethinking the Role of NAIRU in Monetary Policy: Implications of Model Formulation and Uncertainty, in Taylor, J.B. (ed): Monetary Policy Rules, NBER and University of Chicago Press, Chicago.

Favero, C.A., 2002, Taylor Rules and the Term Structure, IGIER Working Paper No. 195.

Favero, C.A., and F. Milani, 2001, Parameter Instability, Model Uncertainty and Optimal Monetary Policy, IGIER Working Paper No. 196.

Favero, C.A, and R. Rovelli, 2003, Macroeconomic stability and the preferences of the Fed. A formal analysis, 1961-98, Journal of Money, Credit, and Banking, forthcoming.

Gerlach, S., and G. Schnabel, 2000, The Taylor rule and interest rates in the EMU area, Economics Letters, 67, 165-171. 
Gerlach-Kristen, P., 2002, Interest Rate Smoothing: Monetary Policy Inertia or Unobserved Variables? A Comment on Rudebusch's "Term Structure Evidence on Interest-Rate Smoothing and Monetary Policy Inertia", mimeo.

Goodfriend, M., 1991, Interest Rate Smoothing and the conduct of monetary policy, Carnegie-Rochester Conference of Public Policy, 7-30.

Goodhart, C., 1999, Central Banks and Uncertainty, Bank of England Quarterly Bulletin, February, 102-121.

Guha, D., and L. Hiris, 2002, The aggregate credit spread and the business cycle, International Review of Financial Analysis, 11, 219-227.

Judd., J.P., and G.D. Rudebusch, 1998, Taylor's Rule and the Fed: 1970-1997, Economic Review, Federal Reserve Bank of San Francisco, 3, 3-16.

Kim, D.H., D.R. Osborn, and M. Sensier, 2002, Nonlinearity in the Fed's Monetary Policy Rule, mimeo.

Kozicki, S., 1999, How Useful Are Taylor Rules for Monetary Policy?, Economic Review, Federal Reserve Bank of Kansas City, 5-33.

Kydland, F., and E.C. Prescott, 1977, Rules Rather than Discretion: The Inconsistency of Optimal Plans, Journal of Political Economy, 85, 473491.

Lansing, K., 2002, Real-time estimation of trend output and the illusion of interest rate smoothing, Economic Review, Federal Reserve Bank of San Francisco, 17-34.

Ljungqvist, L., and T.J. Sargent, 2000, Recursive Macroeconomic Theory, The MIT Press.

Lowe P., and L. Ellis, 1997, The Smoothing of Official Interest Rates, in P. Lowe (ed.): Monetary Policy and Inflation Targeting, Proceedings of a Conference, Sidney: Reserve Bank of Australia.

Mayer, T., 2002, The Macroeconomic Loss Function: A Critical Note, CESIFO Working Paper No. 771, September.

McCallum, B.T., 1999, Issues in the Design of Monetary Policy Rules, in J.B. Taylor and M. Woodford (eds.): Handbook of Macroeconomics, Amsterdam, North-Holland.

Mehra, Y., 2001, The Taylor principle, interest rate smoothing and Fed policy in the 1970s and 1980s, Manuscript, Federal Reserve Bank of Richmond.

Onatski, A., and J.H. Stock, 2002. Robust monetary policy under model uncertainty in a small model of the US economy, Macroeconomic Dynamics 6. 
Orphanides, A., 1998, Monetary Policy Evaluation with Noisy Information, Finance and Economics Discussion Series Working Paper No. 1998-50, Board of Governors of the Federal Reserve System.

Orphanides, A., 2001, Monetary Policy Rules Based on Real-Time Data, The American Economic Review, 91(4), 964-985.

Peersman G., and F. Smets, 1999, The Taylor Rule: A Useful Monetary Policy Benchmark for the Euro Area?, International Finance, 2(1), 85-116.

Perez, S.J., 2001, Looking back at forward-looking monetary policy, Journal of Economics and Business, 53, 509-521.

Roberts, J.M., 1998, Inflation Expectations and the Transmission of Monetary Policy, Board of Governors of the Federal Reserve System, Finance and Economics Discussion Series, No. 1998-43.

Rogoff, K., 1985, The Optimal Degree of Commitment to an Intermediate Monetary Target, The Quarterly Journal of Economics, 100(4), 1169-1189.

Rudebusch, G.D., 2001, Is the Fed too timid? Monetary policy in an uncertain world, Review of Economics and Statistics, 83, 203-217.

Rudebusch, G.D., 2002a, Term structure evidence on interest rate smoothing and monetary policy inertia, Journal of Monetary Economics, 49, 11611187.

Rudebusch, G.D., 2002b, Assessing Nominal Income Rules for Monetary Policy with Model and Data Uncertainty, Economic Journal, 112, April, 402-432.

Sack, B., 1998, Uncertainty, Learning, and Gradual Monetary Policy, Finance and Economics Discussion Series Working Paper No. 1998-34, Board of Governors of the Federal Reserve System.

Sack, B., 2000, Does the Fed Act Gradually? A VAR Analysis, Journal of Monetary Economics, 46, 229-256.

Sack, B., and V. Wieland, 2000, Interest-Rate Smoothing and Optimal Monetary Policy: A Review of Recent Empirical Evidence, Journal of Economics and Business, 52, 205-228.

Sargent, T.J., 1999, Comment, In: John B. Taylor (Ed), Monetary policy rules. Chicago University press.

Söderlind, P., 1999, Solution and estimation of RE macromodels with optimal policy, European Economic Review, 43, 813-823.

Söderlind, P., U. Söderström, and A. Vredin, 2002a, Taylor Rules and the Predictability of Interest Rates, mimeo. 
Söderlind, P., U. Söderström, and A. Vredin, 2002b, Can a Calibrated NewKeynesian Model of Monetary Policy Fit the Facts?, SSE/EFI Working Paper Series in Economics and Finance No 511, September.

Söderström, U., 1999, Should Central Banks Be More Aggressive?, Sveriges Riksbank, Working Paper No. 84, May.

Söderström, U., 2002, Monetary Policy with Uncertain Parameters, Scandinavian Journal of Economics, 104 (1), March 2002, 125-145.

Srour, G., 2001, Why Do Central Banks Smooth Interest Rates?, Bank of Canada Working Paper No. 2001-17.

Staiger, D. and J.H. Stock, 1997, Instrumental Variables Regression with Weak Instruments, Econometrica, 65(3), 557-586.

Surico, P., 2002, US Monetary Policy Rules: the Case for Asymmetric Preferences, FEEM Working Paper No. 66-2002.

Surico, P, 2003, Measuring the Time-Inconsistency of US Monetary Policy, available at http://www.uni-bocconi.it/index.php?frcnav=@10\%2C999\%2C13285

Taylor, J.B., 1993, Discretion versus policy rules in practice, Carnegie-Rochester Conference Series on Public Policy, 39, 195-214.

Wieland, V., 2000, Monetary Policy, parameter uncertainty and optimal learning, Journal of Monetary Economics, 46, 199-228.

Woodford, M., 1999, Optimal Monetary Policy Inertia, NBER Working Paper No. 7261. 


\section{European Central Bank working paper series}

For a complete list of Working Papers published by the ECB, please visit the ECB's website (http://www.ecb.int).

I 13 "Financial frictions and the monetary transmission mechanism: theory, evidence and policy implications” by C. Bean, J. Larsen and K. Nikolov, January 2002.

I 14 "Monetary transmission in the euro area: where do we stand?" by I. Angeloni, A. Kashyap, B. Mojon, D. Terlizzese, January 2002.

II5 "Monetary policy rules, macroeconomic stability and inflation: a view from the trenches" by A. Orphanides, December 200I.

II 6 "Rent indices for housing in West Germany 1985 to 1998" by J. Hoffmann and C. Kurz., January 2002.

117 "Hedonic house prices without characteristics: the case of new multiunit housing" by O. Bover and P. Velilla, January 2002.

118 "Durable goods, price indexes and quality change: an application to automobile prices in Italy, 1988-98” by G. M. Tomat, January 2002.

II9 "Monetary policy and the stock market in the euro area" by N. Cassola and C. Morana, January 2002.

120 "Learning stability in economics with heterogeneous agents" by S. Honkapohja and K. Mitra, January 2002.

121 “Natural rate doubts" by A. Beyer and R. E. A. Farmer, February 2002.

122 "New technologies and productivity growth in the euro area" by F. Vijselaar and R. Albers, February 2002.

I 23 "Analysing and combining multiple credit assessments of financial institutions" by E. Tabakis and A. Vinci, February 2002.

124 "Monetary policy, expectations and commitment" by G. W. Evans and S. Honkapohja, February 2002.

I 25 “Duration, volume and volatility impact of trades” by S. Manganelli, February 2002.

126 "Optimal contracts in a dynamic costly state verification model" by C. Monnet and E. Quintin, February 2002.

127 "Performance of monetary policy with internal central bank forecasting" by S. Honkapohja and K. Mitra, February 2002.

128 "Openness, imperfect exchange rate pass-through and monetary policy" by F. Smets and R. Wouters, February 2002. 
129 "Non-standard central bank loss functions, skewed risks, and certainty equivalence" by A. al-Nowaihi and L. Stracca, March 2002.

130 "Harmonized indexes of consumer prices: their conceptual foundations" by E. Diewert, March 2002.

13I "Measurement bias in the HICP: what do we know, and what do we need to know?" by M. A. Wynne and D. Rodríguez-Palenzuela, March 2002.

132 "Inflation dynamics and dual inflation in accession countries: a "new Keynesian" perspective” by O. Arratibel, D. Rodríguez-Palenzuela and C. Thimann, March 2002.

133 "Can confidence indicators be useful to predict short-term real GDP growth?" by A. Mourougane and M. Roma, March 2002.

134 "The cost of private transportation in the Netherlands, 1992-99" by B. Bode and J. Van Dalen, March 2002.

I 35 "The optimal mix of taxes on money, consumption and income" by F. De Fiore and P. Teles, April 2002.

I 36 "Retail bank interest rate pass-through: the new evidence at the euro area level" by G. de Bondt, April 2002.

137 "Equilibrium bidding in the eurosystem's open market operations" by U. Bindseil, April 2002.

138 "New" views on the optimum currency area theory: what is EMU telling us?" by F. P. Mongelli, April 2002.

139 “On currency crises and contagion” by M. Fratzscher, April 2002.

140 "Price setting and the steady-state effects of inflation" by M. Casares, May 2002.

|4I “Asset prices and fiscal balances” by F. Eschenbach and L. Schuknecht, May 2002.

142 "Modelling the daily banknotes in circulation in the context of the liquidity management of the European Central Bank", by A. Cabrero, G. Camba-Mendez, A. Hirsch and F. Nieto, May 2002.

I43 “A non-parametric method for valuing new goods", by I. Crawford, May 2002.

I44 "A failure in the measurement of inflation: results from a hedonic and matched experiment using scanner data”, by M. Silver and S. Heravi, May 2002.

145 "Towards a new early warning system of financial crises", by M. Fratzscher and M. Bussiere, May 2002.

I 46 "Competition and stability - what's special about banking?", by E. Carletti and P. Hartmann, May 2002. 
147 "Time-to-build approach in a sticky price, sticky wage optimising monetary model, by M. Casares, May 2002.

148 "The functional form of yield curves" by V. Brousseau, May 2002.

149 "The Spanish block of the ESCB multi-country model" by A. Estrada and A. Willman, May 2002.

150 "Equity and bond market signals as leading indicators of bank fragility" by R. Gropp, J. Vesala and G. Vulpes, June 2002.

15I "G7 inflation forecasts" by F. Canova, June 2002.

152 "Short-term monitoring of fiscal policy discipline" by G. Camba-Mendez and A. Lamo, June 2002.

153 "Euro area production function and potential output: a supply side system approach" by A. Willman, June 2002.

154 "The euro bloc, the dollar bloc and the yen bloc: how much monetary policy independence can exchange rate flexibility buy in an interdependent world?" by M. Fratzscher, June 2002.

155 "Youth unemployment in the OECD: demographic shifts, labour market institutions, and macroeconomic shocks" by J. F. Jimeno and D. Rodriguez-Palenzuela, June 2002.

156 "Identifying endogenous fiscal policy rules for macroeconomic models" by J. J. Perez, and P. Hiebert, July 2002.

157 "Bidding and performance in repo auctions: evidence from ECB open market operations" by K. G. Nyborg, U. Bindseil and I. A. Strebulaev, July 2002.

158 "Quantifying Embodied Technological Change" by P. Sakellaris and D. J. Wilson, July 2002.

159 "Optimal public money" by C. Monnet, July 2002.

160 "Model uncertainty and the equilibrium value of the real effective euro exchange rate" by C. Detken, A. Dieppe, J. Henry, C. Marin and F. Smets, July 2002.

161 "The optimal allocation of risks under prospect theory" by L. Stracca, July 2002.

162 "Public debt asymmetries: the effect on taxes and spending in the European Union" by S. Krogstrup, August 2002.

163 'The rationality of consumers' inflation expectations: survey-based evidence for the euro area" by M. Forsells and G. Kenny, August 2002.

164 "Euro area corporate debt securities market: first empirical evidence" by G. de Bondt, August 2002. 
165 "The industry effects of monetary policy in the euro area" by G. Peersman and F. Smets, August 2002.

166 "Monetary and fiscal policy interactions in a micro-founded model of a monetary union" by R. M.W.J. Beetsma and H. Jensen, August 2002.

167 "Identifying the effects of monetary policy shocks on exchange rates using high frequency data" by J. Faust, J.H. Rogers, E. Swanson and J.H. Wright, August 2002.

168 "Estimating the effects of fiscal policy in OECD countries" by R. Perotti, August 2002.

169 “Modelling model uncertainty” by A. Onatski and N. Williams, August 2002.

170 "What measure of inflation should a central bank target?" by G. Mankiw and R. Reis, August 2002.

I7I "An estimated stochastic dynamic general equilibrium model of the euro area" by F. Smets and R. Wouters, August 2002.

172 "Constructing quality-adjusted price indices: a comparison of hedonic and discrete choice models" by N. Jonker, September 2002.

173 "Openness and equilibrium determinacy under interest rate rules" by F. de Fiore and Z. Liu, September 2002.

174 "International monetary policy co-ordination and financial market integration" by A. Sutherland, September 2002.

175 "Monetary policy and the financial accelerator in a monetary union" by S. Gilchrist, J.O. Hairault and H. Kempf, September 2002.

176 "Macroeconomics of international price discrimination" by G. Corsetti and L. Dedola, September 2002.

177 "A theory of the currency denomination of international trade" by P. Bacchetta and E. van Wincoop, September 2002.

178 "Inflation persistence and optimal monetary policy in the euro area" by P. Benigno and J.D. López-Salido, September 2002.

179 "Optimal monetary policy with durable and non-durable goods" by C.J. Erceg and A.T. Levin, September 2002.

180 "Regional inflation in a currency union: fiscal policy versus fundamentals" by M. Duarte and A.L. Wolman, September 2002.

181 "Inflation dynamics and international linkages: a model of the United States, the euro area and Japan” by G. Coenen and V. Wieland, September 2002.

182 "The information content of real-time output gap estimates: an application to the euro area” by G. Rünstler, September 2002. 
183 "Monetary policy in a world with different financial systems" by E. Faia, October 2002.

I84 "Efficient pricing of large-value interbank payment systems" by C. Holthausen and J.-C. Rochet, October 2002.

185 "European integration: what lessons for other regions? The case of Latin America" by E. Dorrucci, S. Firpo, M. Fratzscher and F. P. Mongelli, October 2002.

186 "Using money market rates to assess the alternatives of fixed versus variable rate tenders: the lesson from 1989-98 data for Germany" by M. Manna, October 2002.

187 “A fiscal theory of sovereign risk” by M. Uribe, October 2002.

188 “Should central banks really be flexible?" by H. P. Grüner, October 2002.

189 "Debt reduction and automatic stabilisation" by P. Hiebert, J. J. Pérez and M. Rostagno, October 2002.

190 "Monetary policy and the zero bound to interest rates: a review" by T. Yates, October 2002.

191 "The fiscal costs of financial instability revisited" by L. Schuknecht and F. Eschenbach, November 2002.

192 "Is the European Central Bank (and the United States Federal Reserve) predictable?" by G. Perez-Quiros and J. Sicilia, November 2002.

193 "Sustainability of public finances and automatic stabilisation under a rule of budgetary discipline" by J. Marín, November 2002.

194 "Sensitivity analysis of volatility: a new tool for risk management" by S. Manganelli, V. Ceci and W. Vecchiato, November 2002.

195 “In-sample or out-of-sample tests of predictability: which one should we use?" by A. Inoue and L. Kilian, November 2002.

196 "Bootstrapping autoregressions with conditional heteroskedasticity of unknown form" by S. Gonçalves and L. Kilian, November 2002.

197 "A model of the Eurosystem's operational framework for monetary policy implementation" by C. Ewerhart, November 2002.

198 "Extracting risk-neutral probability densities by fitting implied volatility smiles: some methodological points and an application to the 3M EURIBOR futures option prices" by A. B. Andersen and T. Wagener, December 2002.

199 "Time variation in the tail behaviour of bund futures returns" by T. Werner and C. Upper, December 2002. 
200 "Interdependence between the euro area and the United States: what role for EMU?" by M. Ehrmann and M. Fratzscher, December 2002.

201 "Euro area inflation persistence" by N. Batini, December 2002.

202 "Aggregate loans to the euro area private sector" by A. Calza, M. Manrique and J. Sousa, January 2003.

203 "Myopic loss aversion, disappointment aversion and the equity premium puzzle" by D. Fielding and L. Stracca, January 2003.

204 "Asymmetric dynamics in the correlations of global equity and bond returns" by L. Cappiello, R.F. Engle and K. Sheppard, January 2003.

205 "Real exchange rate in an inter-temporal n-country-model with incomplete markets" by B. Mercereau, January 2003.

206 "Empirical estimates of reaction functions for the euro area" by D. Gerdesmeier and B. Roffia, January 2003.

207 "A comprehensive model on the euro overnight rate” by F. R. Würtz, January 2003.

208 "Do demographic changes affect risk premiums? Evidence from international data" by A. Ang and A. Maddaloni, January 2003.

209 “A framework for collateral risk control determination” by D. Cossin, Z. Huang, D. Aunon-Nerin and F. González, January 2003.

210 "Anticipated Ramsey reforms and the uniform taxation principle: the role of international financial markets” by S. Schmitt-Grohé and M. Uribe, January 2003.

211 "Self-control and savings" by P. Michel and J.P. Vidal, January 2003.

212 "Modelling the implied probability of stock market movements" by E. Glatzer and M. Scheicher, January 2003.

213 “Aggregation and euro area Phillips curves” by S. Fabiani and J. Morgan, February 2003.

214 "On the selection of forecasting models" by A. Inoue and L. Kilian, February 2003.

215 "Budget institutions and fiscal performance in Central and Eastern European countries" by H. Gleich, February 2003.

216 "The admission of accession countries to an enlarged monetary union: a tentative assessment” by M. Ca'Zorzi and R. A. De Santis, February 2003.

217 "The role of product market regulations in the process of structural change" by J. Messina, March 2003.

218 "The zero-interest-rate bound and the role of the exchange rate for monetary policy in Japan” by G. Coenen and V. Wieland, March 2003. 
219 "Extra-euro area manufacturing import prices and exchange rate pass-through" by B. Anderton, March 2003.

220 "The allocation of competencies in an international union: a positive analysis" by $M$. Ruta, April 2003.

221 "Estimating risk premia in money market rates" by A. Durré, S. Evjen and R. Pilegaard, April 2003.

222 "Inflation dynamics and subjective expectations in the United States" by K. Adam and M. Padula, April 2003.

223 "Optimal monetary policy with imperfect common knowledge” by K. Adam, April 2003.

224 "The rise of the yen vis-à-vis the ("synthetic") euro: is it supported by economic fundamentals?" by C. Osbat, R. Rüffer and B. Schnatz, April 2003.

225 "Productivity and the ("synthetic") euro-dollar exchange rate" by C. Osbat, F. Vijselaar and B. Schnatz, April 2003.

226 "The central banker as a risk manager: quantifying and forecasting inflation risks" by L. Kilian and S. Manganelli, April 2003.

227 “Monetary policy in a low pass-through environment” by T. Monacelli, April 2003.

228 "Monetary policy shocks - a nonfundamental look at the data" by M. Klaeffing, May 2003.

229 "How does the ECB target inflation?" by P. Surico, May 2003.

230 "The euro area financial system: structure, integration and policy initiatives" by P. Hartmann, A. Maddaloni and S. Manganelli, May 2003.

23I "Price stability and monetary policy effectiveness when nominal interest rates are bounded at zero" by G. Coenen, A. Orphanides and V. Wieland, May 2003.

232 "Describing the Fed's conduct with Taylor rules: is interest rate smoothing important?" by E. Castelnuovo, May 2003. 